\title{
PRÁCTICAS DE NATACIÓN, CUERPO Y OCIO EN UN BALNEARIO DE MAR, ARGENTINA SIGLO XX
}

\section{SWIMMING, BODY AND LEISURE PRACTICES IN THE SEASIDE RESORT, ARGENTINA 20TH CENTURY}

\author{
Gisela Kaczan \\ Universidad Nacional de Mar del Plata (UNMdP/CONICET) \\ gisela.kaczan@gmail.com
}

\begin{abstract}
Resumen:
Este artículo reflexiona sobre las relaciones del cuerpo con el agua y, especialmente, sobre la natación recreativa en las piletas de un balneario de mar, Mar del Plata, Argentina. Se considera que las recomendaciones que en el inicio del siglo XX son prioritarias para asistir a las miradas salutíferas, pasan a ser estímulos de las nuevas experiencias de ocio que surgen hacia la segunda y tercera década del mismo siglo. Para ello, se realiza un abordaje cualitativo, desde la historia cultural, con el aporte de los estudios visuales que destacan el valor de la imagen en la simbólica social. Los resultados muestran los cruces tangibles e intangibles entre el entorno y las experiencias sociales y corporales vinculadas con las prácticas deportivas.
\end{abstract}

Palabras clave: historia cultural- estudios visuales- deporte- salud- ocio- Mar del Plata- Argentina

\begin{abstract}
:
This article reflects on relationships of the body with water, especially the relationship between the body andrecreational swimming in the pools of a seaside resort of Mar del Plata, Argentina. It considers that recommendations at the beginning of the 20th century as priorities for healthful looks also become stimuli of new leisure experiences that arise toward the second and third decades of the same century. For this, we apply a qualitative approach focusing on cultural history along with contributions from visual studies that highlight the value of image as a social symbol. The results show the tangible and intangible interconnections between the environment and the social and corporal experiences associated with sports practices.
\end{abstract}

Keywords: cultural history- visual studies- sport- health- leisure- Mar del Plata- Argentina 


\section{Introducción}

El contacto del cuerpo con el agua acompañó la historia de las culturas.

Con la caída del Imperio romano, al desintegrarse la cultura del hedonismo e instalarse la cultura ascética de la cristiandad, esta situación se habría desarticulado (Lencek y Bosker, 1998). El cristianismo en la Edad Media europea custodió los códigos de la moral y las buenas costumbres y objetó las prácticas de baños en los espacios públicos. Los baños mixtos comenzaron a prohibirse y las termas medievales comenzaron a tener mala reputación. Se hizo más fuerte la idea de que los placeres del cuerpo había que aplacarlos y esta misma representación se transfirió a las prácticas en las costas. Así, la vida frente al mar se la pensó poblada de temores, se lo consideró un lugar que conducía a la promiscuidad.

Prosigue un tiempo en el cual las representaciones sociales resguardan versiones de seres fantásticos, supersticiones y avatares respecto de las profundidades marinas, reelaboradas en la literatura y el arte renacentistas.

Más tarde, el espacio de la playa comienza a percibirse con otros propósitos. En el Romanticismo, se da lugar al mar asociado con la fuerza, lo adverso y las vicisitudes de las tempestades y la inmensidad (Zuppa, 2014). Y, también, se introduce una nueva forma de percibir el paisaje. Se apela a la noción de infinito y de la dispersión de la naturaleza, pasa a ser un sitio para la contemplación y para la práctica de experiencias que conllevan lo sublime. Es en este tiempo, hacia el siglo XVIII, cuando comienza a extenderse la idea de que el mar poseía beneficios, en sincronía con las nuevas preocupaciones de las ciencias médicas.

En este contexto, las playas se incorporarían a los usos culturales con el aliciente terapéutico, la "cura de mar" era una forma de restauración que la ciencia admitía y recomendaba. Según Corbin, para que la ribera pase a ser un punto atractivo, tendrían que difundirse el deseo del espectáculo sublime y el imperativo terapéutico (Corbin, 1993: 93). Aquí, se inscribe el gusto del espectador por contemplar el paisaje de la costa, la necesidad de registrar los sentimientos en un lienzo por parte de los pintores y, también, la mirada atenta sobre el cuidado del cuerpo.

El cuerpo ocupara, a partir de ahora, un lugar inédito. Se pronunciaron prescripciones para activarlo y movilizarlo, se multiplicaron las justificaciones de la gimnasia y los deportes y establever vínculos con la naturaleza.

Este cúmulo de prácticas y creencias se extendió rápidamente en los grupos aristocráticos europeos y resultó un estímulo para un uso novedoso de las riberas que también sería referente para otros territorios como Argentina.

En la playa, se marcará la importancia de implementar actividades físicas antes y después del baño, algunas, costeando la orilla y, cada vez más, la práctica de la natación. La natación será un deporte que asocie la necesidad de mejorar el estado físico, con el espacio natural y el baño.

Entre las novedades, se construyeron piletas al aire para la práctica deportiva en un espacio definido y, por otro lado, también posibilitaron el desarrollo de una práctica social integrativa, vinculada con nuevos estilos de vida y con vivencias que se irán consolidando a medida que se avanza sobre las décadas, disfrutar del ocio y de experimentar desde las sensibilidades.

Por lo señalado, este artículo se propone rastrear las relaciones del cuerpo con el agua, y, puntualmente, indagar en la práctica de la natación recreativa, no como 
objeto de estudio sino, como medio para adentrarse en algunas de las convenciones y transformaciones culturales que se fueron generando en las primeras décadas del siglo XX.

Se considera que las recomendaciones que en el inicio del siglo $X X$ son prioritarias para asistir a las miradas salutíferas, como el acercamiento a la naturaleza y la movilización del cuerpo en el agua, pasan a ser estímulos que abastecen las nuevas experiencias de hedonismo y ocio que surgen hacia la segunda y tercera década del mismo siglo. En este pasaje se pueden registrar algunas de las redes tendidas entre cuerpo, cultura, deporte, tiempo libre, así como transparentar las representaciones que acompañaron estos procesos.

Esto, asimismo, tiene su correspondencia en el espacio, en la intervención del paisaje costero y en la incorporación del agua y del mar al imaginario social.

El territorio es la ciudad de Mar del Plata, al sudeste de la provincia de Buenos Aires, Argentina, por ser el primer territorio del país donde se instalan las estancias balnearias.

Para demostrar lo planteado, el artículo presenta, en el inicio una reseña sobre aspectos del deporte y la natación a lo que le siguen los modos de abordaje desde el marco de la historia cultural y los estudios visuales. Luego, se desarrollan las miradas terapéuticas sobre el agua como medio para la higiene y el bienestar del cuerpo, lo que motiva la incorporación del baño de mar y sus rituales. Esto último conlleva registrar el inicio de los balnearios de mar y el desarrollo de una nueva infraestructura como las piletas, las actividades que allí se albergan y su impacto en la simbólica social. Por último se hace foco en las marcas de género que condicionan disposiciones particulares para las mujeres en los primeros años del siglo XX.

\section{Encuadre}

\subsection{Aproximaciones teóricas}

El deporte ha sido una temática poco atractiva para el saber científico hasta no hace tanto tiempo, cuando con la apertura de las ciencias sociales a partir del llamado giro cultural, comenzó a ser posible estudiar a los actores, sus subjetividades y la dimensión simbólica de sus prácticas. En este sentido, las primeras incursiones de Elías, Dunning (1992) y Gutmann (1978) pusieron de relieve la especificidad del deporte y la importancia de su estudio en el contexto donde se desarrollaba. Los aportes como los de Bourdieu (1991), Vigarello (1982, 2005, 2006, 2007), Chartier (1982) entre otros, reconocieron que las prácticas deportivas constituyen espacios sociales relacionales y conectados con las demás áreas de la vida social.

Estas prácticas tienen un cuerpo específico en la medida en que se instalan, de manera inédita, tanto en el espacio y el tiempo como en el tejido de la comunidad (Chartier, Vigarello, 1982) por lo cual pueden reflejar las condiciones que acontecen en el entorno donde se desarrollan. Pero también, de acuerdo con P. Bourdieu, la historia del deporte es relativamente autónoma; incluso cuando graves acontecimientos económicos y sociales influyen sobre ella, ésta tiene su propio ritmo, sus propias leyes de evolución, sus propias crisis, en resumen, su cronología específica (Bourdieu, 1992). Así, se tiene el convencimiento de que las prácticas deportivas pueden ser una lente a través de la cual examinar, reenfocar incluso profundizar cuestiones 
incontestadas sobre las ciencias políticas, la historia cultural, la antropología social, la historia del cuerpo, entre otras tantas.

Es, al mismo tiempo, un fenómeno cultural complejo en el que la experiencia corporal es una condición indefectible. Se pone en juego el cuerpo y se objetivan diferentes dimensiones y representaciones de su contexto, las de disciplinamiento y control, las políticas y patrióticas, las científicas e higiénicas, las lúdicas, las estética.

De acuerdo con esto, Vigarello $(1982,2005,2006)$ señala que el deporte se enfoca hacia un control del cuerpo según unas modalidades que tienden a sustituir la disciplina visible de la gimnasia por coacciones abstractas y colectivamente interiorizadas de las reglas a respetar, de las tácticas a seguir, de los records a superar. Nace en una etapa en la cual se miró al cuerpo desde el punto de vista de su eficiencia mecánica, proveniente de una nueva percepción del trabajo, análoga a la del gesto industrial racionalizado de la época. Se basa en la necesidad de una apreciación cuantitativa del esfuerzo muscular, el cuerpo está totalmente tecnificado, se desplegaron principios relacionados con propiciar vigor y los desplazamientos fueron fragmentados. Se acrecentaron los preceptos pedagógicos en las instituciones educativas apuntando a la uniformidad de las posturas.

En este marco se inscribe el desarrollo de la natación, largamente ignorada, dada la escasez de estudios en relación con el interés que han despertado otros deportes, como el fútbol o las gimnasias. Estudios señuelos en Inglaterra y Estados Unidos son una contribución al debate. En el caso de Inglaterra, de acuerdo con Love (2008) la práctica de nadar fue disfrutada por diversos grupos de la sociedad inglesa y reflejó sus prejuicios sociales, preconceptos, contradicciones e ideales, así como acompañó las consecuencias de las nuevas formas de ocio de la sociedad inglesa, como la emergencia del ocio popular.

En el contexto norteamericano, el estudio de Wiltse (2007) sobre las piletas municipales le permitió analizar las tensiones y transformaciones que dieron lugar a la vida moderna de los estadounidenses e interpretar las estrategias de segregación racial, las relaciones intergenéricas, las diferencias de clase social. Así, estos destinos de recreación le permitieron avistar el pasaje de una sociedad industrial a una moderna.

En el contexto argentino se reconocen trabajos sobre la natación que avanzan sobre algunos ejes principales. A saber, aquellos que se vinculan con los desarrollos científicos en biomecánica, aquellos que se concentran en las incumbencias de la profesionalización, como en las características competitivas y de rendimiento de la modalidad deportiva, aquellos que estudian la incorporación de la natación en los sistemas educativos, ya sea discusiones sobre los diseños curriculares, su instrumentación, la modalidad de la formación docente, entre otros aspectos. ${ }^{1}$

De allí, que este artículo proponga una perspectiva interdisciplinar que ponga el foco, a través de la interpretación de textos e imágenes, en la natación recreativa como práctica que transparenta algunas de las grandes transformaciones y pasajes que atraviesan los cuerpos de mujeres y varones en los primeros años del siglo XX. Especialmente se ocupa de hallar las relaciones tangibles e intangibles entre el entorno natural y construido de las piletas, las experiencias sociales y corporales junto a los significados, todos puestos en relación.

1 Entre la bibliografía que se ha consultado para hacer este relevamiento se reconocen especialmente, las actas de las diferentes ediciones del Congreso Argentino y Latinoamericano de Educación Física y Ciencias, Facultad de Humanidades y Ciencias de la Educación, Universidad Nacional de La Plata, Buenos Aires, Argentina. 


\subsection{Modos de abordaje}

Para dar cuenta de las interacciones propuestas se resuelve un abordaje cualitativo y se adhiere a una nueva forma de hacer historia, a leer las señales a través de una historia dinámica y en transformación que resalta el interés por conocer los vínculos entre cultura y sociedad prestando atención a todas las fuentes (Burke, 2000, Le Goff, Chartier, Revel, 1988). Se propone, con respecto a cuestiones puntuales, operar desde la microhistoria (Levi, 1993) como práctica historiográfica basada en la reducción de la escala de observación. Esta metodología permite el estudio intensivo y denso del material documental (Geertz, 1992), el descubrimiento de organizaciones conceptuales y la profundización de las herramientas de análisis y de los métodos existentes.

Como forma de articulación de lo propuesto, se delinea una instancia de análisis relacional que parte de la observación de las imágenes, desde los aportes recientes de los estudios de la cultura visual (Brea, 2005, Didi-Huberman, 2008, Mitchel, 2005, Moxey, 2009). Los estudios visuales se aproximan a la comprensión de las imágenes entendiendo que son parte integrante de la comunicación humana a través de metáforas visuales de registro, no menos ciertas que las secuencias ordenadas y lineales de las palabras (Bohem, 1994). Exploran el rol de la imagen en lo cotidiano, sin reducirla exclusivamente a las lecturas canónicas e introducen cuestionamientos vinculados tanto con el objeto de estudio como con los procederes y métodos que facilitan el acceso a su comprensión. Esto significa que se incluyen todos los modos de expresión visual, se da la posibilidad de confiar en los juicios de valor y se recurre a enfoques interdisciplinares que abarquen las múltiples dimensiones de lo visual. Este campo se vuelve de interés para la sociología visual y para otras disciplinas, como la historia, en cuanto ejercicio analítico de las dimensiones visuales de la vida social (Cabrera y Guarín, 2012).

Por lo dicho, se ha apelado a un complejo corpus de fuentes de investigación que aportan, desde su especificidad, miradas múltiples que ayudan a componer desde la coyuntura político cultural, pasando por las características de los emplazamientos urbanos y sus improntas turísticas, hasta referir las modas y modos de comportamientos sociales y apariencias permitidas. Se han consultado y puesto en diálogo: revistas ilustradas de interés general, revistas que versan sobre aspectos de la salud, literatura sobre el deporte, manuales y guías para bañistas, guías turísticas, postales y fotografías, avisos publicitarios (en las revistas y en las guías mencionadas). En cada uno de los casos se atiende a la articulación entre la información de los textos y la del contenido visual, para enriquecer las interpretaciones.

\section{Agua y cuerpo}

Hacia el siglo XIX, los efectos nocivos de vivir en las grandes ciudades, como el hacinamiento, la contaminación y sus patologías suscitaron, dentro de la corriente del higienismo, que las ciencias médicas participaran activamente para prevenir, reformar, administrar el mundo social y urbano en crecimiento, con estrategias correctivas y de orden como intereses de estado (Armus, 2007, Aresti, 2001). Se otorgó gran atención al entorno natural y social de los enfermos dado que se consideraba que era a través de una cuidada vigilancia que se podía controlar la evolución y la transmisión de las afecciones. Entre las innovaciones, se iniciaron estudios relativos a la curación por medio del agua. Respondía a la idea de prevención de la salud, porque luchaba contra la transmisión y el contagio, con la idea de purificación en tanto que la limpieza 
garantizaba la pureza espiritual y con la noción de bienestar ya que se creía que la limpieza era la fuente de los sentimientos de comodidad y placer. Se acometió una variedad amplia de tratamientos, incorporando los avances que la química aportaba sobre aguas minerales y marinas (Bouza, 2000) que incluían baños turco-romanos, de inmersión, vapor, minerales, alcalinos, sulfurosos, aromáticos, de afrecho y almidón, finlandeses, duchas frías y escocesas, lluvias, pileta, jabonaduras.

Paralelamente, la recomendación del descanso se volvió una tendencia creciente, el objetivo era huir de las aglomeraciones y pasar una temporada lejos de los centros urbanizados. Las excursiones al campo y a la montaña fueron, en un principio, los destinos elegidos. Prontamente y en cruce con la predisposición a favor de la hidroterapia, proliferaron las estancias de baño termal, los spa y se difunde la idea de visitas a estaciones balnearias. En este marco surge el encuentro con la costa y la playa para las curas de mar.

Según los expertos, las aguas de mar ofrecían varias ventajas frente a los baños de tina. Por un lado, en ellas obraban las características farmacológicas de las partículas disueltas de yodo y bromo descubiertas por las investigaciones médicas. Asimismo, era importante la temperatura, siempre más fría que el ambiente, y la acción mecánica de la ola al romperse y azotar en el cuerpo del bañista. Esto representaba un saludable choque, un "masaje natural de positivo beneficio salutífero" (Plus Ultra, 1922, $n^{\circ} 70$ ) para el sistema nervioso actuando mucho más sobre las condiciones fisiológicas. Lo recomendable era entrar y salir al mar varias veces, de esta manera, la acción sucesiva, caliente y fría del sol y del baño, ponía en juego la activación de los centros de termo-regulación (circulación, respiración, oxigenación, nutrición) y, con ello, se tenía el convencimiento de que aumentaba la vitalidad de las funciones digestivas y asimilatorias, la fuerza muscular, la sensación de bienestar y equilibrio físico y moral (Bauza, 1935).

A esto se sumaban las condiciones del entorno, como la posibilidad de absorber los beneficios que la gama de rayos solares aportaba a través de la piel y las propiedades de pureza y oxígeno del aire costero.

En síntesis la cura de mar, lograba una acción saludable y tónica y la activación energética del organismo durante la vida en la playa, era una forma de rejuvenecimiento que la ciencia admitía y recomendaba (Viva Cien Años, 1942, n8).

Con la inauguración de la práctica, se inauguran protocolos y normalizaciones, como las destrezas permitidas de acuerdo con edades y sexos, horarios y tiempos de duración. ${ }^{2} Y$ se inauguran representaciones que, en ocasiones, se alimentan del imaginario y de las suposiciones aunque, algunas encontraran cierto asidero en las recomendaciones de la medicina. Por ejemplo, se recomendaba que el primer "baño

2 En las villas balnearias de diferentes partes de Europa y Estados Unidos se confeccionaron manuales de uso y actividades en la playa. Entre ellos se han hallado los del Balneario del Sardinero y el de La Asociación Médica de Cambridge "Actividades en la playa a finales del XIX y principios del siglo XX" con las siguientes indicaciones: "El primer Baño de Ola no debe realizarse hasta dos días después de la llegada al punto costero, una vez que el individuo se haya aclimatado al nuevo ambiente. Las horas de baño más favorables son entre las diez y las cinco de la tarde, y a ser posible con marea alta, porque el agua estará más caliente, más limpia y próxima, y las olas son más numerosas. El Baño de Ola no debe tomarse en reposo, debe estar precedido de un ligero ejercicio físico o de la exposición al sol. La inmersión en el mar debe ser completa y rápida, sin indecisión, por lo que así la sensación de escalofrío primario se reduce al mínimo en intensidad y duración. La duración del baño no excederá de los veinte minutos. Después, la piel debe frotarse rápidamente con una toalla seca. Enseguida, como antes del baño, es necesario realizar algún ejercicio suave muscular" (Staffe, 1899). 
de ola" no debía realizarse hasta dos días después de la llegada al punto costero, una vez que el individuo se hubiera aclimatado. O se animaba a los bañistas a tomar vinos de Málaga antes de entrar al mar, como estímulo al coraje. Era necesario abstenerse del baño después de una noche de insomnio, pasada en el baile o después de ciertos ejercicios físicos, como el de andar en bicicleta. Y se creía peligroso nadar cuando se estaba muy emocionado (Fray Mocho, 1914, n¹35). Se han visto numerosos argumentos similares y curiosos.

La conciencia del valor terapéutico era tal que se sugería consultar al médico, a fin de que le indicara si su cuerpo estaba en condiciones o si le recomendaba el descanso en el marco de otro paisaje. Desde un manual de natación escrito por un reconocido nadador y profesor argentino, se propone que en las municipalidades de las ciudades costeras podrían implementarse "consultorios médicos" con el objeto de aconsejar e indicar las reglas que debían seguirse para instruir a los veraneantes (Bauza, 1928).

\section{Balnearios y piletas: inicio de la natación recreativa}

En Argentina todas estas prácticas fueron absorbidas por los grupos aristocráticos del país y las llevaron a cabo en un sector amplio de la naturaleza costera sobre el océano Atlántico. La incipiente ciudad de Mar del Plata, en la zona sur de la provincia de Buenos Aires, luego de una modificación de su función como enclave productivo, se convirtió en una estación balnearia fundada, como tantas otras villas europeas, por los grupos de las elites nacionales. ${ }^{3}$

La inauguración de las playas se dio en la zona central, que se conocería con el nombre de playa Bristol, donde confluían usos portuarios que prontamente fueron trasladados. Hacia el norte, la topografía del paisaje inspiró y se formó otro sector atractivo para que en la temporada de los años 1886-1887 se generaran los primeros balnearios de las playas del norte, una de ellas Rambla Norte, tiempo después conocida con el nombre de La Perla, el Balneario La Estrella Argentina y luego el Balneario San Sebastián Argentino. Se generó una amplificación posterior hacia el sur con el balneario de Playa Grande y el Complejo de Punta Mogotes.

En el inicio, los servicios no resultaron demasiado complejos, se atendía la seguridad de los bañistas mediante el uso de sogas que se internaban con postes enclavados hasta alcanzar una atinada profundidad del mar, formas de resolver un salvataje con sandolines a cargo de un salvavidas y casillas o caperos para resguardar el pudor y el temor de las mujeres. En este contexto, podría pensarse que la máquina de baño fue una de las primeras estructuras, pequeñas arquitecturas que se diseñaron para el contacto con el agua (Gray, 2006). Casillas de madera con ruedas que tenían la función de trasladar a las bañistas hacia el mar para que pudieran desarrollar la práctica y, luego, acercarlas nuevamente a la arena (Figura 1)

3 Entre los principales factores que favorecen el atractivo de Mar del Plata, además de la corriente del higienismo,se reconoce la interrupción de los viajes a Europa a causa de la guerra, lo que conlleva a los grupos enriquecidos a buscar un lugar dentro del país donde pasar la temporada. Se empieza a invertir en Mar del Plata mediante la instalación de grandes viviendas, de un lujoso hotel y la extensión del ferrocarril que posibilita la accesibilidad (Pastoriza,2002, Zuppa, 2012). 

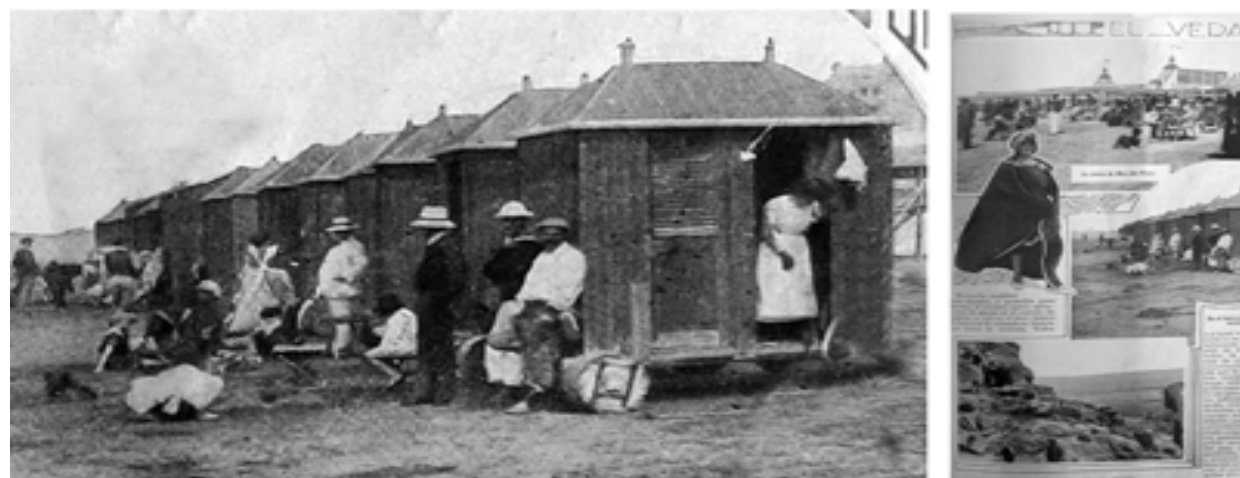

Figura 1:Caras y Caretas (1914). Buenos Aires, año XVII, $\mathrm{n}^{\circ} 803$.

En el marco de las corrientes terapéuticas mencionadas líneas arriba, eran los enfermos y débiles los que se acercaban a tomar los baños pero, también, se reunían cada vez con mayor afluencia, grupos familiares para desplegar prácticas de sociabilidad sobre la arena. Siguiendo a Corbin (1993), en las zonas costeras se va a concretar un espacio diferente que posibilita un vasto repertorio de sensaciones placenteras dentro de una vida social específica: se codifican experiencias personales y usos grupales, se perfilan procedimientos de sociabilidad y mecanismos de distinción simbólica que tutelan al espectáculo social de los grupos privilegiados que inicialmente conquistan las riberas. Por esta razón, desde emprendimientos privados y estatales se pensó el diseño de arquitecturas públicas sobre el margen oceánico, que otorgaban no solo prestaciones asociadas con los baños sino, también, salas de lectura, ramblas para pasear con instalaciones para realizar compras o bares dancings y clubes donde reunirse para tomar aperitivos, conversar y distraerse durante la estadía de verano.

Entre las novedades, se construyeron piletas de natación, en la cercanía al mar y al aire libre. Estas estructuras instrumentan un espacio apto para la práctica protegida del baño y de la natación, sin los temores de la resistencia que ofrecían las olas o los efectos de la marea y con el aporte de las propiedades del agua marina.

Sus antecedentes se encuentran en las piscinas flotantes instaladas en ríos y mares, desde principios del siglo XVIII, con dependencias que ofrecían comodidades funcionales a los usuarios. La contaminación de las aguas hizo que estas estructuras fueran reemplazándose por receptáculos de agua en condiciones higiénicas con técnicas cada vez más precisas para purificarlas (Cortés, 2010).

De acuerdo con Cortés (2010) las piletas son pensadas como formas arquitectónicas independientes y específicas, la caja que contiene el agua se ubica en el centro y la circundan los servicios de camarines y baños asociados directamente a las funciones de cuidado de la salud e higiene personal. Y, a su vez, es un espacio público de encuentro intergenérico que conecta una serie de actividades culturales que favorecieron la sociabilidad con el descanso y la práctica del deporte (Figura 2 y Figura 3). 


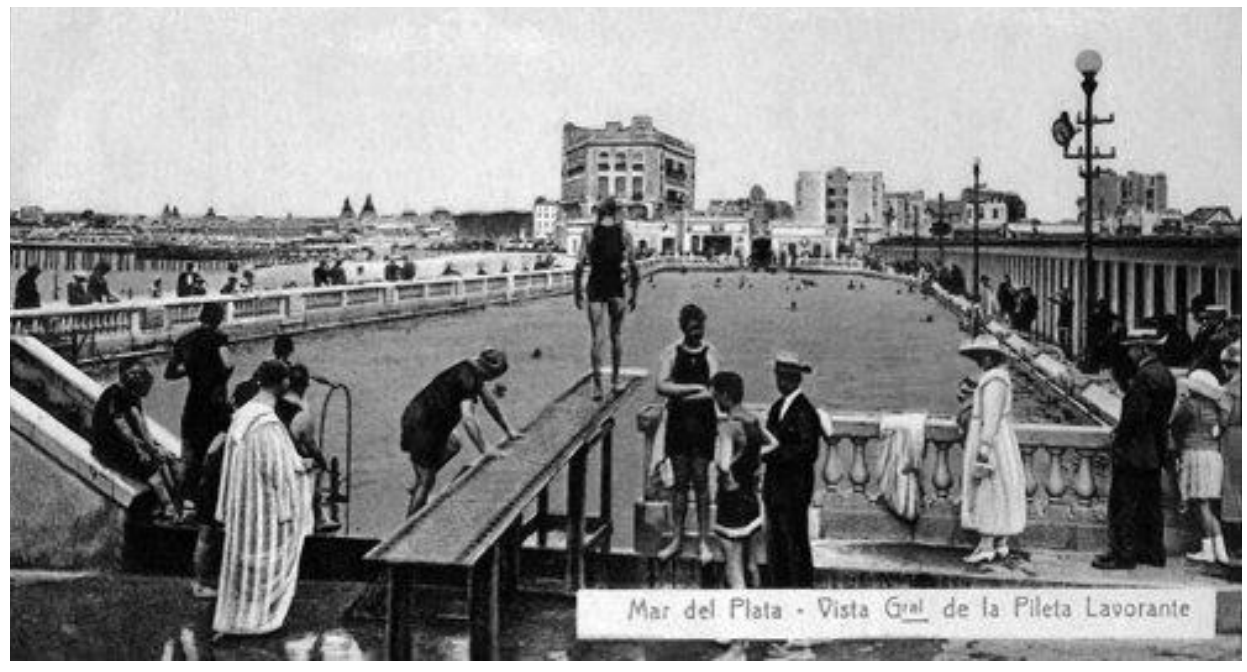

Figura 2: Pileta Lavorante, postal, s/f. Archivo Fotos de Familia. Diario La Capital. Mar del Plata.

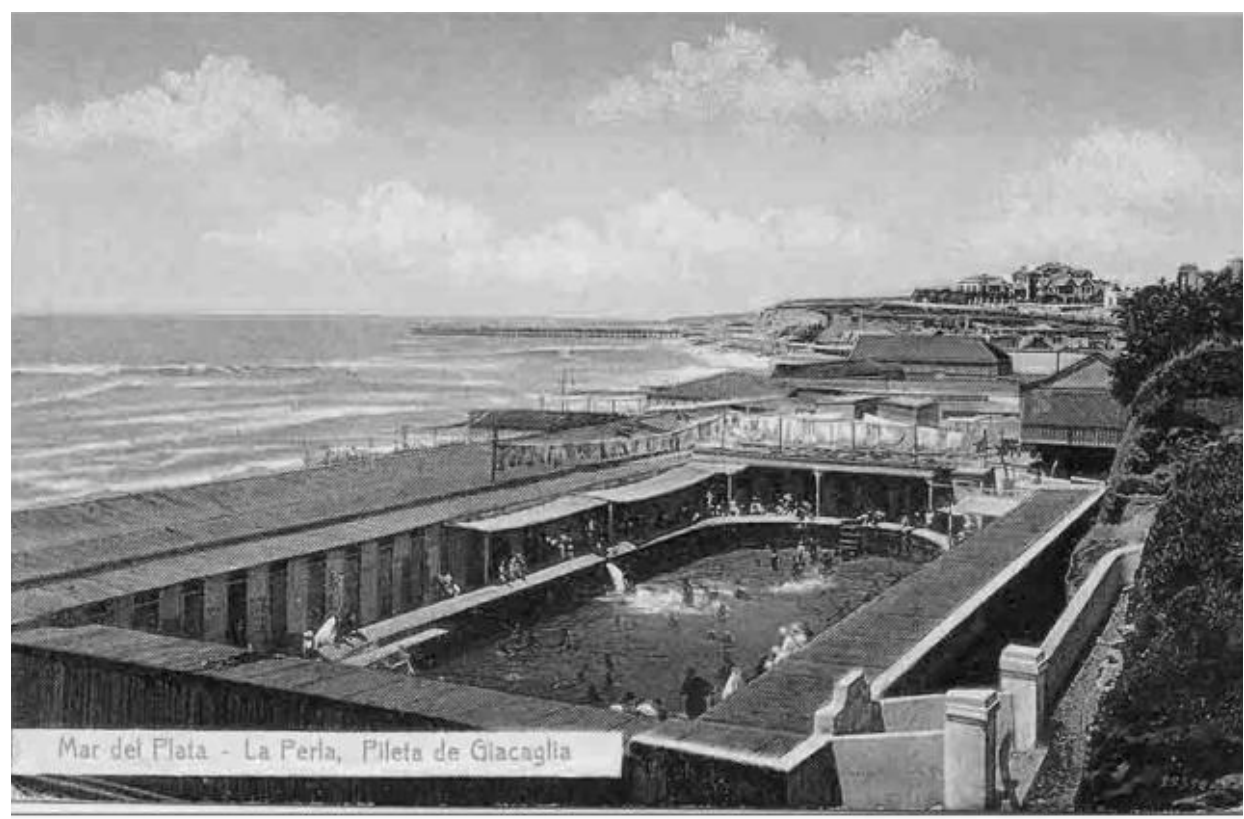

Figura 3: Pileta Giacaglia, postal, s/f. Archivo Fotos de Familia. Diario La Capital. Mar del Plata.

La primera pileta construida en Mar del Plata fue conocida como "Pileta Lavorante", fundada por el ingeniero Vicente Lavorante hacia mediados de la década de $1910 .{ }^{4}$ Estaba ubicada sobre Punta Iglesia, en uno de los lugares de paisaje más atractivo y accesibles de la ciudad. Esta pileta era la mayor del país, $20 \mathrm{~m}$ de ancho x $100 \mathrm{~m}$ de

$4 \quad$ Mar del Plata tiene una impronta migratoria muy fuerte en su génesis, lo que significa que los primeros inversionistas son, mayoritariamente, extranjeros. Redes familiares y amicales de inmigrantes crearon los primeros asentamientos balnearios marcando un sesgo identitario que aún hoy puede rastrearse en el perfil patrimonial de la ciudad. 
largo, un complejo que se genera aprovechando el sótano de una barraca existente para construir la pileta, cambiadores para los bañistas, un balneario, confitería y un espigón deportivo en el primitivo muelle. Para 1928 se menciona la existencia de cinco piletas de natación donde el agua de mar era cambiada diariamente y renovada de continuo (Comisión Pro Mar del Plata, 1928).

En este estado del recorrido, cabe preguntarse ¿cuáles son las actividades principales que se realizaban en las piletas?

Las fuentes consultadas advierten el desarrollo de baños sueltos y la asistencia a clases colectivas de natación y gimnasia diariamente durante la temporada veraniega. La promesa era que los profesores de natación en pocas lecciones enseñaban a nadar y con un gasto insignificante. Se expendían abonos y vales para baños y se suministraban trajes y sábanas (Comisión Pro Mar del Plata, 1928).

La natación como deporte en las piletas, en estrecha relación con los balnearios, facilitó el papel terapéutico decisivo del agua, sus beneficios y las reacciones del cuerpo con el líquido elemento, tal como se apuntó líneas arriba en relación con el mar.

Desde las alabanzas de las miradas científicas, se asiente que la natación, en la parte de motricidad, es un gran ejercicio como normalizador del cuerpo y actividad de superación personal. Desde el punto de vista de la salud, representaba un sinnúmero de ventajas que todos deberían aprovechar. Se prescribe que es un deporte fortificante y completo, con efecto descongestionante, relajante de la musculatura, quitaba la tensión del sistema nervioso y no se marcan distinciones de edad ni de género, aunque prevalezcan algunos prejuicios de larga data. Estimula las funciones orgánicas $\mathrm{y}$, al mismo tiempo, permite al organismo librarse del cúmulo de toxinas producidas por el trabajo sedentario y por la escasa actividad de la vida moderna (Viva Cien Años, 1940, $n^{\circ}$ 6).

Se sugiere empezar a nadar a la edad de entre cinco y diez años y practicar regularmente. En la revista ilustrada Caras y Caretas, de 1909 se advierte que entre los quince y los cuarenta años, la habilidad de aprender desaparece para luego ser más fácil mantenerse a flote, una construcción ilusoria que no deja de atraer por su fortuita y curiosa advertencia (Caras y Caretas, 1909, $n^{\circ} 538$ ).

Lo apropiado era ejecutar la práctica bajo la tutela de un entrenador competente. En los primeros tiempos la figura era la del bañero, como retratan las revistas. Hacia la segunda década del siglo XX ya se trata de jóvenes deportistas, instructores de natación, formados para comprender al alumno y facilitar sus primeros ensayos en instalaciones deportivas y escuelas.

Surge una literatura específica que apuntala el trabajo físico como proyecto indispensable para transformar el aspecto corporal y, también circulan descripciones aportadas por los textos, no todos académicos, como las revistas de interés general, destinadas a un público heterogéneo, sobre todo de las grandes ciudades. En estas últimas, con marcado interés por hacer extensivas formas de disciplinar los cuerpos, era frecuente que entre sus secciones se intercalaran noticias sobre los deportes de moda, como la natación, sus cualidades, beneficios e indicaciones de los procederes. De tal manera, las diferentes posiciones y maniobras básicas de propulsión, ataque o salto y respiración eran complementadas con el valor de la imagen que hacía tangible la visualización de la destreza para el lector inexperto (Figura 4).

Se insiste en la actividad hecha a conciencia, con voluntad y concentración, donde nada debía quedar al azar. El acento estaba puesto en la intensidad, regularidad, 
constancia y esfuerzo como medios para sacar el mejor provecho. Emerge lentamente un universo que hasta entonces no había estado muy presente en las prácticas corporales: el de los músculos sometidos a esfuerzo, analizados, concientizados (Vigarello, 2006).

Hay quienes preferían el aprendizaje dentro del agua. En el primer caso, el cuerpo quedaba sujeto por un cinturón a una cuerda unida a un cable alto, con una rueda que permite correr hacia atrás y hacia adelante mientras queda sobre la superficie con total movilidad. Una alternativa era que el instructor se sumerja en el agua y sostenga al aprendiz ayudándolo a realizar las posiciones.

Otra de las teorías más aceptadas era nadar "en seco" es decir, en tierra, con el fundamento de que hay que saber sumergirse en el aire antes de hacerlo en el agua. Para ello se empleaba un asiento o tabla que sostenía al alumno en posición horizontal dejando piernas y brazos libres para movilizarse de acuerdo con el estilo pautado (Figura 5).

Según las opiniones autorizadas las posturas más cómodas y naturales para la natación eran dos: o con el cuerpo echado de espaldas o boca abajo, nunca en la colocación de lado que, además, parecía ser poco elegante en las señoritas.

En cuestión de pedagogías, el mercado también hizo sus ofertas. Aparatos especialmente indicados para la enseñanza, como el cuello Mackintosh, que consistían en una especie de plato inflado que se colocaba alrededor del cuello e impedía el hundimiento del cuerpo (Figura 6). Se complementaba con algunos accesorios para "mecerse cómoda y seguramente al impulso de las olas" como islas y asientos flotantes o como el "Mar-o-Plano", "tanto para los hábiles cultores de la natación como para los que no saben nadar" un juego de palabras que da idea de un artefacto similar al aeroplano pero, para usar en el agua (Caras y Caretas, 1927, $n^{\circ} 1479$ ). Los profesores no los recomendaban.

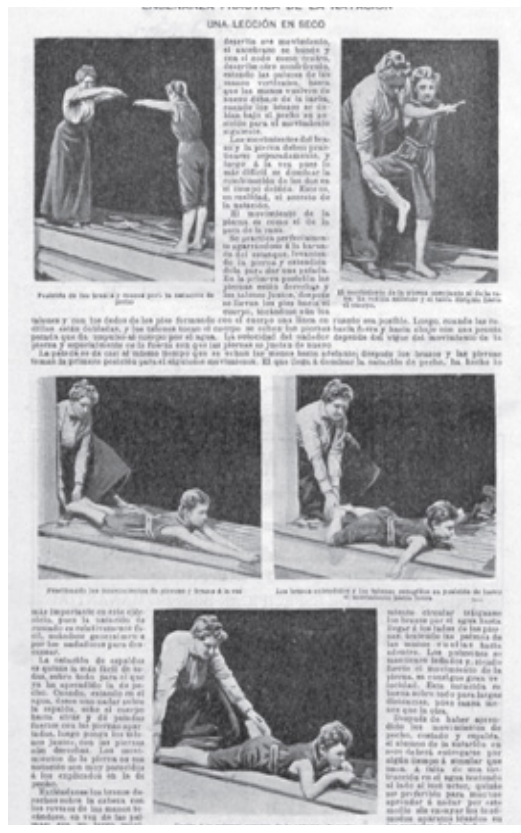

Figura 4: Caras y Caretas (1902). Buenos Aires, año V, n¹75. 


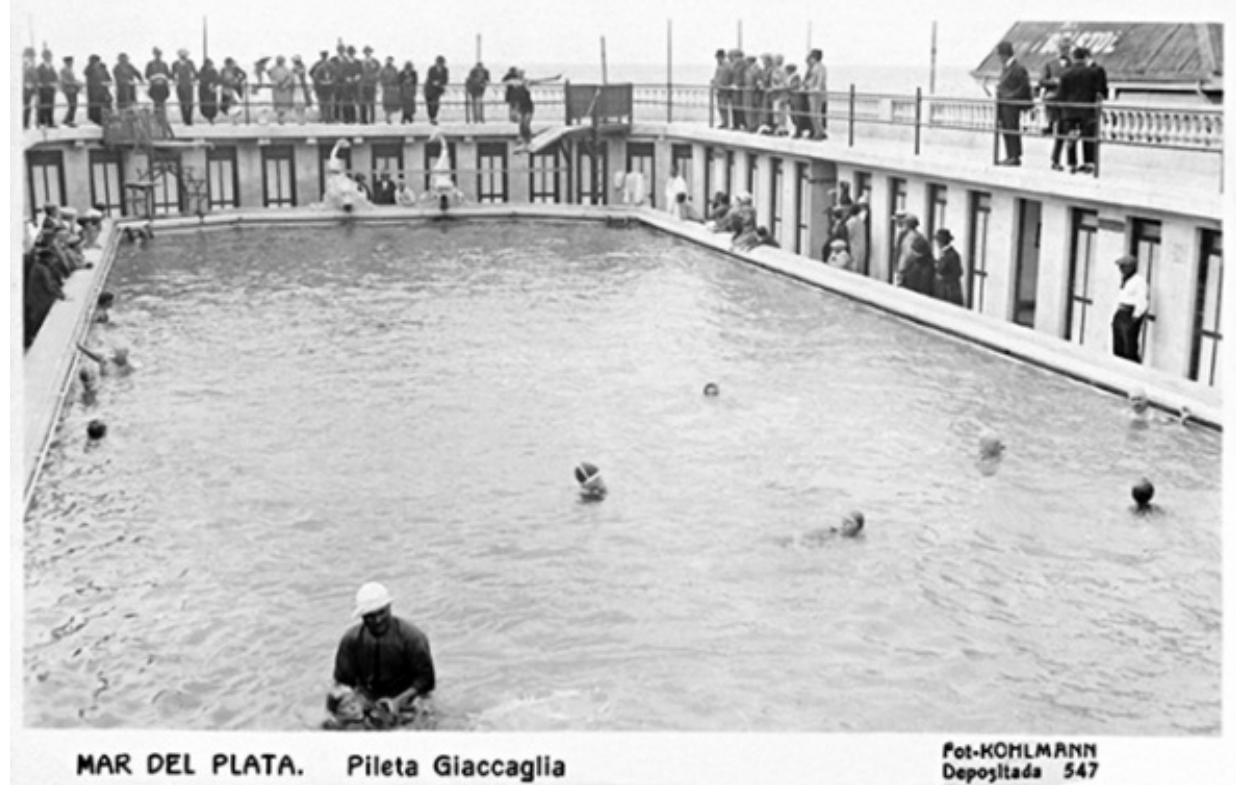

Figura 5: Pileta Giacaglia, clases de nado, circa 1920. Archivo Fotos de Familia. Diario La Capital. Mar del Plata.

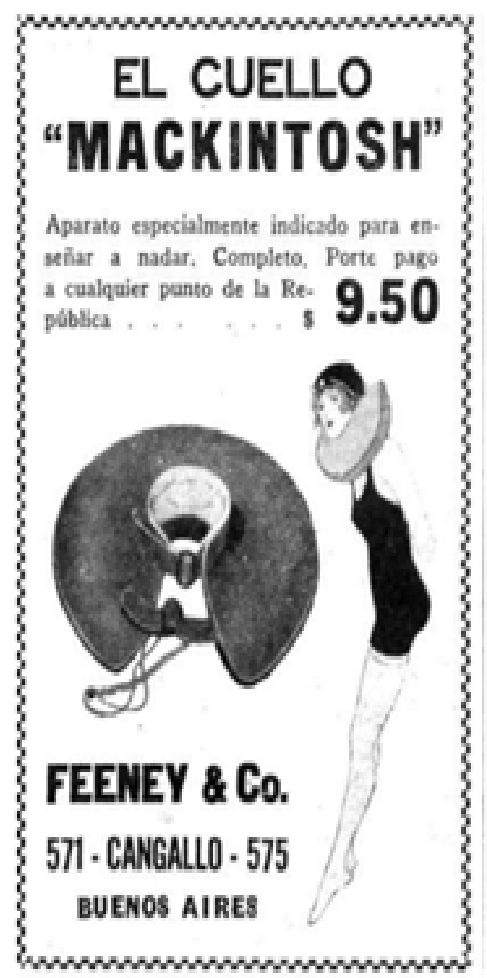

Figura 6: Aviso Mackintosh. Caras y Caretas (1927). Buenos Aires, año XXX, nº 1479. 
El objetivo del aprendizaje no apuntaba a la formación profesional únicamente. Varios títulos y tópicos se refieren al deporte como "gran pasatiempo durante el verano", una práctica asociada directamente con las posibilidades de disfrutar del mar y la playa con otros fines más que los salutíferos. Hacia fines de la primer década del siglo XX, la revista Caras y Caretas señala que en el contexto inglés, la natación se consideraba como uno de los pasatiempos más agradables y más higiénicos en la temporada de verano, situación que antes era bastante rara, no estaba de moda y los baños públicos eran pocos y poco frecuentados. ${ }^{5}$

Esto va a introducir otra faz de la práctica deportiva en la cercanía al mar. Una faz que viene de la mano de incorporar formas del ocio y del esparcimiento en el tiempo libre y en contacto con la naturaleza.

\section{Nuevas experiencias: arribo del ocio y del placer}

“(...) Solamente los que toman baños medicinales, se los dan en silencio; pero los que se lo toman por placer o por higiene (que es lo mismo), cantan, ríen, silban moviéndose alegremente en sus bañaderas (...). ¿Y en las playas balnearias? ¿no es aquello un jolgorio, un bullicio, un verdadero delirio de placer? (...) (Caras y Caretas, 1909, $n^{\circ} 537$ ).

En esta frase se registra una temprana correspondencia con las licencias para gozar, públicamente y sin prejuicios, de un tipo de bienestar ligado a las experiencias de ocio. Es una situación que se vuelve más recurrente a medida que se avanza sobre las décadas, una posibilidad del individuo moderno, el arribo de otras sensibilidades más ligadas a lo subjetivo y corpóreo.

En este sentido, la transmisión de doctrinas sobre las propiedades terapéuticas de las aguas marinas como elemento natural, junto a la apreciación del clima y las condiciones del paisaje, provocaron la revalorización de prácticas deportivas en su función restauradora y de entretenimiento. En sincronía, los avances en la medicina y la aplicación de los descubrimientos químicos y bacteriológicos transfieren e instalan los tratamientos a enfermos en centros clínicos y hospitalarios. Entonces, los balnearios pierden prestigio higiénico y sanitario y, poco a poco, pasan a ser lugares de alojamiento turístico, donde el contacto con el agua se convierte en excusa para integrar actividades lúdicas (Villar Molina, 2004).

Mar del Plata no es ajena a este proceso, todo lo contrario, lo manifiesta, hay un compromiso explícito desde las políticas del Estado por satisfacer las expectativas en boga.

Durante las décadas de 1920 y 1930 se concretan obras públicas con el gradual mejoramiento de los caminos que incentivan el traslado de bienes, servicios, viajeros, sobre todo desde la capital del país, Buenos Aires, hacia Mar del Plata (Piglia, 2014). Las empresas de transporte otorgan facilidades y se difunde el acceso y uso del automóvil en las clases sociales más acomodadas y en los sectores medios emergentes. Más tarde, hacia la década de 1940 la presidencia de turno reivindica derechos laborales y muy pronto se democratizan las vacaciones y se multiplican los servicios sindicales en los centros de veraneo, como Mar del Plata. El carácter público y social del balneario conjuga nuevos usos sobre el tiempo libre para las vacaciones y en

5 La referencia de Inglaterra no parece casual, no solo por la inauguración de las prácticas deportivas en este contexto (Elías y Dunning 1992) sino, también, porque es allí donde se asientan las primeras estaciones balnearias en el continente europeo (Corbin,1993, Walton, 2008) 
el lugar de entretenimientos y reposo. Esto conlleva una significativa distancia a la serenidad salutífera de los primeros tiempos, la playa actual se caracterizará por su banalidad, un sitio expresamente social, con pluralidad de visitantes.

Dada la aceptación de la práctica y el interés político por responder a estas demandas y ofrecer servicios, hacia 1929 la Pileta Lavorante, que es destruida por un temporal, pasa a manos de la Municipalidad del partido presidida por el Intendente José Camuso. Las instalaciones son reconstruidas y habilitadas para uso público y gratuito.

Es interesante reflexionar sobre algunos puntos de este decreto de pasaje de manos privadas a posesión del municipio. Una serie de disposiciones para los concurrentes, que va desde cuestiones administrativas hasta el tipo de indumentaria permitido deja reflexionar, para empezar, sobre pertenencias sociales. ${ }^{6}$

En relación con esto, como se dijo, en el decreto se libera el uso gratuito al servicio público. Con estas obras, se legitima el papel del Estado en la promoción y fomento de programas para atender la salud, la higiene y la integración social y, así, favorecer actitudes más higiénicas para todos aquellos que quisieran gozar de los beneficios del agua y del deporte, de una forma racional. Se trata de una concepción pública y abierta de la arquitectura del descanso (Cortés, 2010), un recurso que servía para inculcar hábitos ligados con los valores de la cultura física, al mismo tiempo que se aseguraba un empleo positivo del tiempo libre de los grupos trabajadores.

Estaba su contraparte, la concurrencia a las piletas como pasatiempos de mujeres y varones ociosos que perfilaban la categorización de un estereotipo excluyente en

6 Pileta Municipal de Punta Iglesia (Decreto del 30-1935):

"Líbrese gratuitamente al servicio público con fecha $1^{\circ}$ de Febrero del corriente año la Pileta Municipal de Natación, situada en Punta Iglesia".

\section{Reglamento:}

Artículo $1^{\circ}$-El uso de la Pileta de Natación, y sus dependencias es público y gratuito, como asimismo la asistencia a las clases colectivas de natación y gimnasia que se dicten diariamente durante la temporada veraniega, bajo el horario que establezca la Dirección, hoy a cargo del profesor de Educación Física de la Universidad Nacional de La Plata, Don Ernesto Bauzá.

Artículo $2^{\circ}$-Los concurrentes a la Pileta, deberán observar las siguientes disposiciones:

a)-Inscribirse previamente en la Dirección, la que podrá exigir certificado médico de buena salud; no serán admitidos los que padezcan enfermedades infecto-contagiosas.

b)-La Dirección entregará a cada inscripto un carnet, que este deberá presentar cada vez que haga uso de la Pileta, para munirse previamente de la chapa correspondiente que llevará prendida en un lugar visible. La pérdida de la chapa obligará al reembolso de su valor.

c)-El traje de baño de colores firmes, deberá ser de lana o algodón y hasta cubrir el cuerpo, quedando prohibido el uso de Eslifer (tapa-rabo).

d)-Los que practiquen los cursos de gimnasia o cualquier ejercicio físico deberán tomar una ducha completa antes de utilizar la Pileta.

Artículo $3^{\circ}$-Es facultad de la Dirección adoptar cualquier medida en salvaguardia de la salud de los que concurran a practicar la natación y en lo que respecta al orden general.

Artículo $4^{\circ}$-Queda reservado el uso de la Pileta, exclusivamente para señoras y niñas en los días jueves de cada semana.

Artículo $5^{\circ}$-Los infractores a estas disposiciones serán primeramente amonestados y su reincidencia dará lugar al retiro del carnet. 
busca de distinción. Como todos los espacios sociales, el uso de las piletas estaba marcado por una fuerte pertenencia de clase social, como ampliamente a demostrado Bourdieu (1991), desde la crítica sociológica. Un acceso selectivo permitía una opción segregada de la actividad de los otros. En consecuencia, los balnearios y sus piletas se concibieron con diferentes objetivos y, por tanto, con distintos programas. En Mar del Plata, los grupos más encumbrados eligieron la pileta del balneario de Playa Grande, por ejemplo, que se encontraba distanciada de las piletas céntricas y más populares.

Aunque entre las aspiraciones del deporte moderno esté la voluntad de desdibujar las diferencias de clase, no puede escapar de las determinaciones sociales que reintroducen en un campo supuestamente impermeable las propiedades, los objetivos o simbolismos de los practicantes. Cada uno es portador de una identidad social fuerte y específica (Chartier y Vigarello, 1982: 291). La elección de una instalación balnearia para la práctica de la natación depende, en un grado del capital económico y, en segundo lugar, del capital cultural y del tiempo libre (Bourdieu, 1992: 178). Esto significa que en las piletas, el acceso delineaba un estilo de vida, más asociado con prácticas que permitieran formar parte de un grupo y de una clase que con actividades deportivas o de descanso propiamente dichas.

En el decreto impera, también, el sentido de moral y decencia en relación con las características del traje de baño: "de colores firmes, deberá ser de lana o algodón y hasta cubrir el cuerpo, quedando prohibido el uso de Eslifer (tapa-rabo)" (Decreto municipal, 1935). Desde la normativa se intentó atenuar la carga sexual provocada en el uso de la pileta por ambos géneros y limitar el exhibicionismo y el voyeurismo exigiendo trajes de baño mesurados.

En este sentido, la revelación del cuerpo, que acompaña el proceso de aproximación al agua, ensaya formas desconocidas de exhibirse y ocultarse en el espacio de lo público. Los cuerpos que quedaban amparados por la indumentaria en el ámbito social, adquieren, ahora, transparencia. ${ }^{7}$ El traje de baño es funcional a la incorporación de hábitos corporales vinculados con las destrezas y la disciplina deportiva. Pero también es funcional a activar la curiosidad y el deseo sexual. La meta del observador es más el deleite de una desnudez potencial que la desnudez en sí misma. La censura del traje no permite conocer demasiado, pero sí imaginar y, allí los límites son infinitos. En las imágenes se comprueba el contraste entre quienes visten como bañistas y quienes no participan de la práctica. La bata como sobreprenda es la encargada de preservar el pudor apenas se finalizan las habilidades en el agua.

Por otro lado, se manifiesta un tiempo diferenciado del uso del espacio de la pileta entre mujeres y varones. No se da en simultáneo y, se marca que queda reservado exclusivamente para señoras y niñas un día de la semana.

Vale señalar que la sexualización de los lugares tiene una historia trazada por los discursos dominantes sobre los comportamientos particulares entre mujeres y varones de acuerdo a las subjetividades que le vendrían dadas por sus características biológicas. Estas preocupaciones legitimaron la construcción de espacios físicos separados para controlar mejor a las personas-cuerpos que los ocupaban. Las diferencias

7 En un principio, se llevaba una camisa de manga corta unida a un calzón abullonado por medio de una pequeña falda, más bien para disimular las caderas que como accesorio distintivo. Para las mujeres, el uso de la gorra era sin excepción. Con el paso del tiempo, este diseño se fue reemplazando por una túnica que descendía por debajo de la rodilla y, hacia la década de 1920 con la incorporación del maillot, las formas se simplifican de tal manera que varones y mujeres confunden sus siluetas (Kaczan, 2012). 
entre lo femenino y lo masculino se conciertan en construcciones socioculturales y, como correlato, los usos, prácticas y apropiaciones del espacio se dan en consecuencia, se producen y reproducen junto a todo aquello que une simbólicamente al sujeto con su lugar.

Con el modelo de familia que se implanta hacia mediados del siglo XIX se traza una fuerte tensión sexual entre las incompatibilidades de derechos y obligaciones; de roles y funciones; criterios de valoración, virtudes y condenas entre los dos sexos. De allí que estos preceptos estén cruzados con las sensibilidades del pudor y la moral y que deban ser registrados, también en las formas de disponer de los espacios para la recreación y la práctica de deportes. Derivada de una tradición religiosa occidental que enlaza el placer con los malos sentimientos, con lo inmoral, con lo culposo, la sexualidad es bien vista sólo con fines de reproducir la especie, mientras que lo que provoca placer es considerado una transgresión (Lamas, 2002). Razón por la cual, la separación era ineludible.

Estas dos últimas situaciones serán retomadas en un apartado sobre las marcas de género, ubicadas hacia el final del artículo.

En este contexto, las actividades acuáticas ganan en adhesión y se diversifican. Una propaganda de la revista Atlántida de 1940, de la Asociación de Propaganda y Fomento de Mar del Plata pone en evidencia los atractivos turísticos del balneario que, ahora, están al alcance de todos (Figura 7).

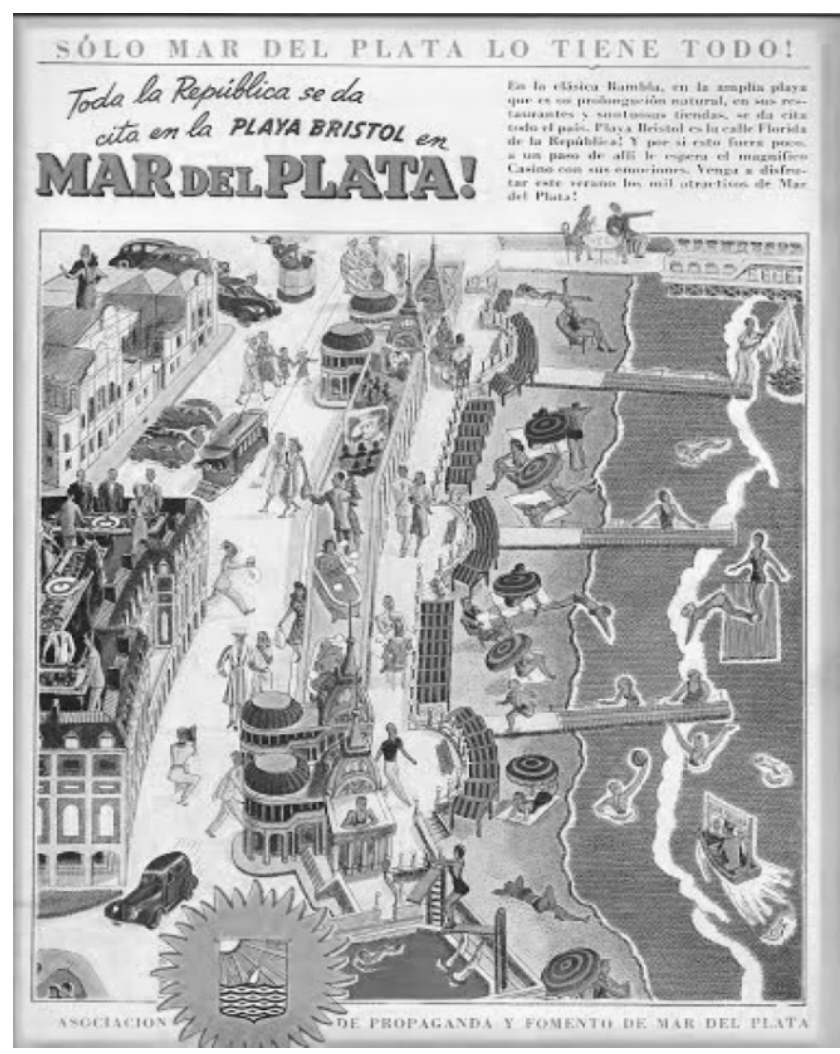

Figura 7: Aviso Publicitario Asociación de Propaganda y Fomento. Revista Atlantida (1940). Buenos Aires, $\mathrm{s} / \mathrm{n}^{\circ}$. 
En la mitad izquierda se ofrecen diversiones en el escenario urbano y en la mitad derecha, todo tipo de entretenimiento sobre la playa y sobre el mar. Se distingue una amplia oferta de deportes acuáticos, usos del mar, zambullidas, nado, pesca, water polo, lancha, y el uso de las piletas, con la representación de una de ellas, situada contigua a la rambla y a la arena en el ángulo inferior derecho. Los recursos expresivos del ilustrador reflejan con un alto grado de iconicidad la afinidad con el agua y sus efectos vinculados al placer.

La playa, y en ellas las piletas, se convirtieron en emblemas de una nueva versión, claramente moderna, de la vida que apreciaba el ocio, el disfrute y lo natural. Paralelamente, se modifican los comportamientos, los gestos y los códigos acordes con las modalidades de integración social así, también se modifican los patrones culturales de decencia pública. Los cuerpos vestidos y pasivos se van suplantando por encuentros cercanos e inquietos en maillots que redundan en las figuras dinámicas de los bañistas de agua y de sol. El tamaño de los trajes se redujo para mostrar con mayor fidelidad la topografía corporal, la objetivación pública del cuerpo se volvió implícitamente aceptable, aunque no dejaba de provocar controversias, como se verá líneas adelante.

Ahora, se da lugar al trabajo sobre uno mismo. Hay un acercamiento a la exploración de lo sensible y a transformar las vías del ejercicio y lo que se espera de él. En capas más profundas, el entrenamiento moviliza, entre las décadas de 1920-1940, un trabajo sobre la intimidad, el control, no solo de los músculos y de los movimientos, sino de lo sensible, de la interioridad (Vigarello, 2006).

Si bien la práctica de la natación se desarrolla en base a una rutina de entrenamiento y a estilos previamente pautados, el contacto profundo con el agua aviva el abandono controlado, sobre todo en un medio ajeno a las variaciones de las olas y los imprevistos, como las piletas.

La literatura más o menos científica marcaba que era necesario escuchar los mensajes internos y dejarse llevar:

"...cuando nos lanzamos dentro del agua ésta nos proporciona un suave masaje (...) al ceder y estrecharse a nuestro alrededor mientras ejecutamos los movimientos para desplazarnos (...) para nadar (...) dejarnos acariciar por el agua" (Viva Cien Años, 1940, $n^{\circ} 7$ ).

Los territorios naturales renuevan el objeto del trabajo sobre uno mismo en virtud del placer despreocupado, el cuerpo puede tratar de ser atlético, esforzarse más, ocupar un tiempo que no se le había dado antes mientras se lo cuida. Y se activan sensaciones que se encuadran en el concepto de flow (Csikszentmihalyi, 1990), desde el fenómeno del ocio, como una actividad en la cual se pierde la noción del tiempo y se vive una gran satisfacción, donde el estado del cuerpo participa activamente. ${ }^{8}$

La relación entre naturaleza, bienestar y emociones del cuerpo, referirán un diseño que active los sentidos, la motivación será crear un ambiente propio simulando lo natural en los emplazamientos del entorno de las piletas. Así como en otros contextos, los americanos, por ejemplo, las piletas pasaron a ser destinos con césped o arena,

8 Cuando el contacto con el agua es anhelado, se esfuman los límites del mundo conocido y, en un punto, la memoria del cuerpo se puebla de sensaciones emotivas, de vivencias y sensibilidades que pueden rememorar la génesis de cada uno, meses previos al nacimiento. Esto provoca las fibras íntimas, ajenas al dominio de la razón, como si el agua contuviera por las fuerzas de gravedad, entonces se pierden todas las prevenciones, se olvidan las preocupaciones y el cuerpo se dedica a accionar libremente dentro de un elemento que no es habitual. 
pudiendo el bañista salir de su camarín a la playa, descansar bajo sombrillas o practicar la helioterapia al aire libre.

Las Figuras 8, 9 y 10 ponen en evidencia cómo la pileta Municipal es circundada por una amplia terraza y una superficie de playa artificial que, además de los servicios mencionados, tenía en especial consideración las necesidades de los niños, dado el amplio repertorio de juegos, tradicionalmente instalados en plazas, como toboganes, hamacas y calesitas (Imagen 8).

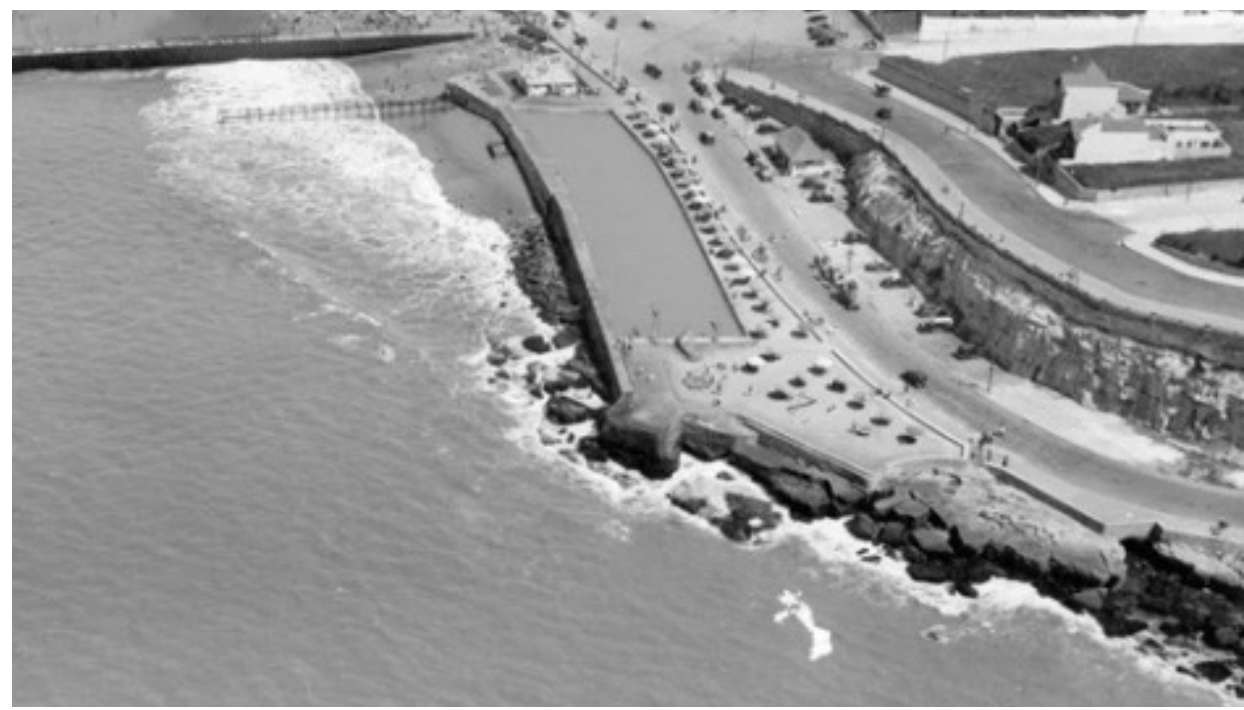

Figura 8: Pileta Municipal, vista panorámica del entorno, 1937. Archivo Fotos de Familia. Diario La Capital. Mar del Plata.

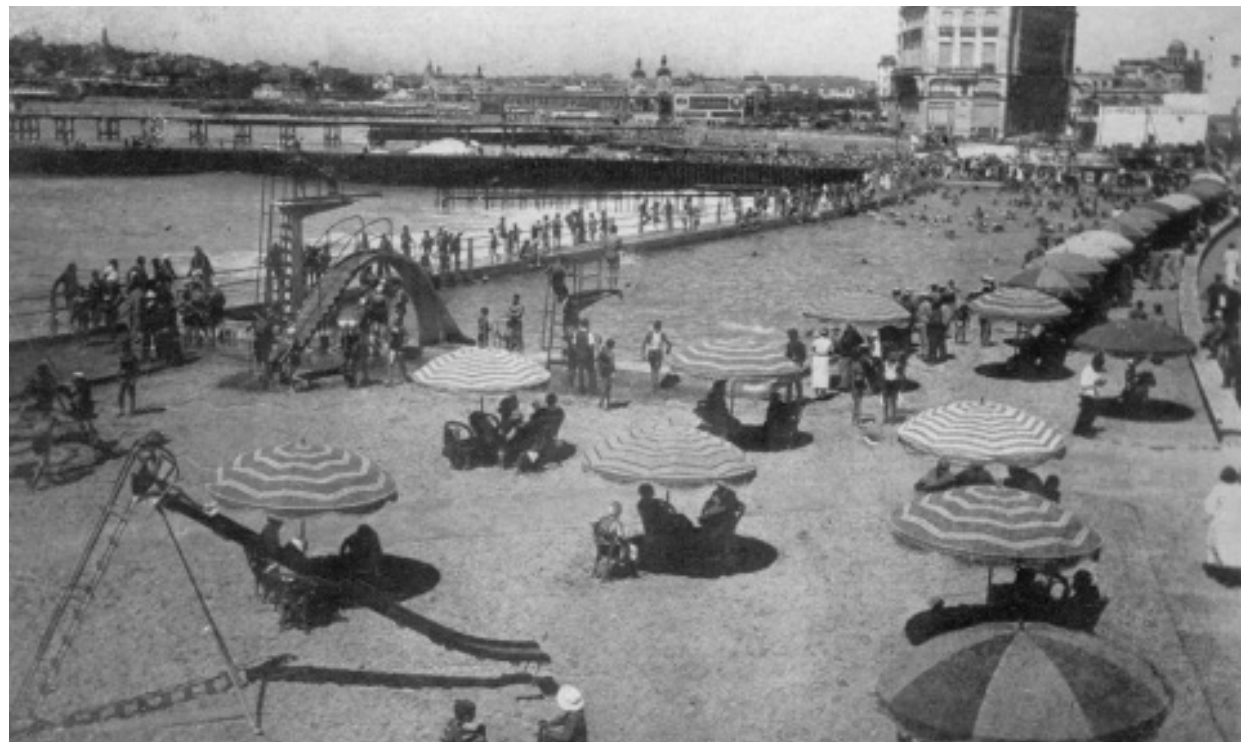

Figura 9: Pileta Municipal, detalle de sombrillas con playa artificial en el extremo norte. Boletín Municipal 1935. Archivo Fotos de Familia. Diario La Capital. Mar del Plata. 


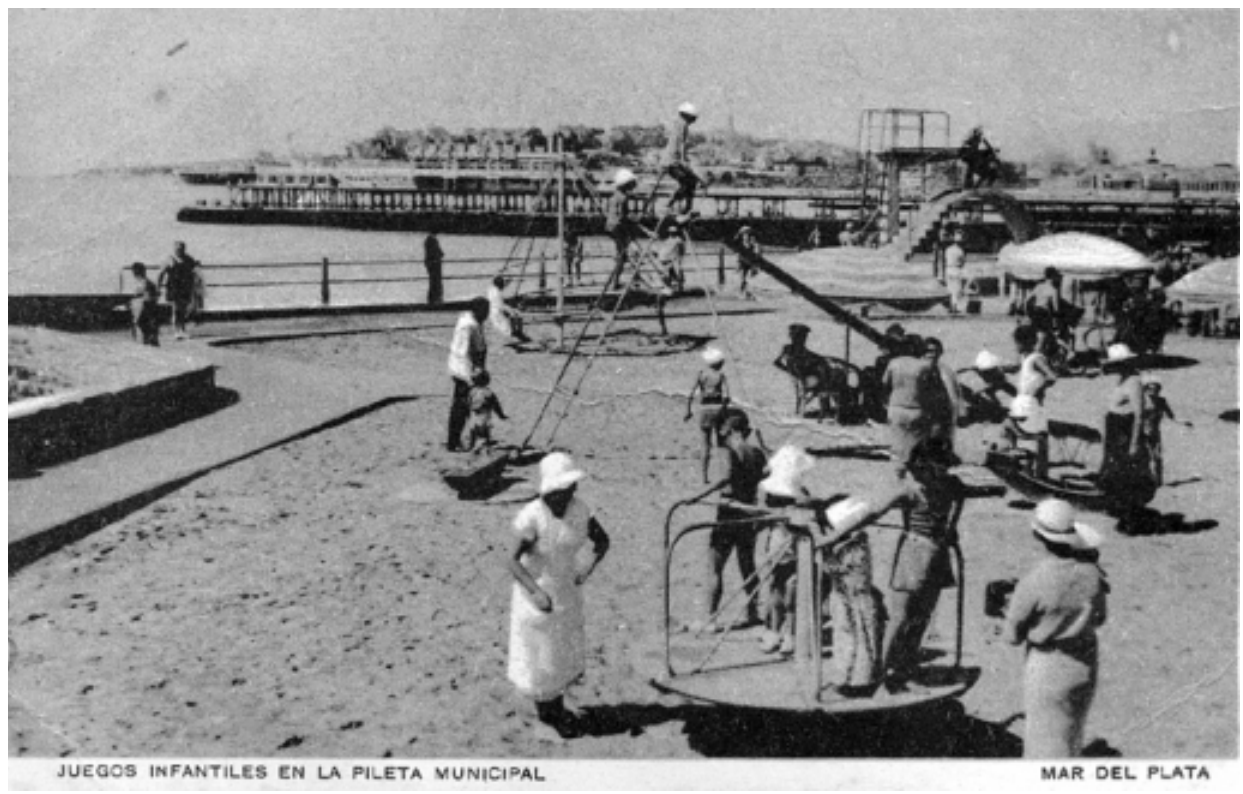

Figura 10: Pileta Municipal, detalle de juegos, circa 1930. Archivo Fotos de Familia. Diario La Capital. Mar del Plata.

En la misma línea, las piletas dan lugar a la experimentación de las emociones desde otro lugar, desde la observación. Fotografías y postales dejan ver que, en ocasiones, había más espectadores que practicantes. En este sentido, si el mar albergaba raides y hazañas de nadadores reconocidos y otros anónimos, la pileta va a dar lugar a competencias que se constituyen en sí mismas en una atracción multitudinaria (Figura 11).

El espectáculo, sea cual sea, atrae desde las primeras décadas del siglo XX para miradas cada vez más numerosas (Vigarello, 1992). Se percibe la efervescencia en la participación de eventos en las piletas públicas, aglomeraciones de observadores que revisten atención y desorden.Al principio, no hay gradas pensadas para organizar y contener, los espacios que rodean la caja de agua son estrechos y de circulación. Aunque algunas piletas tuvieran un perímetro cerrado, como estructuras de madera con lonas de tela que hacen invisible lo que sucede dentro, desde otros ángulos, como la altura de la rambla, los curiosos se las ingeniaban para conseguir una ubicación que les diera una panorámica privilegiada de los cuerpos en el agua (Figura 12).

No solo se albergaba al deporte, los requerimientos primarios eran reemplazados por otras funciones. La Pileta Municipal fue acondicionada para una ópera hacia 1935 (Figura 13) o en el balneario La Perla, para la década de 1930 la pileta de PieriniGiaccaglia, fue vaciada para la instalación de un ring donde se practicaba boxeo. Se disponen sillas improvisadas para varias filas de espectadores, estrechamente dispuestas alrededor de la pileta. 


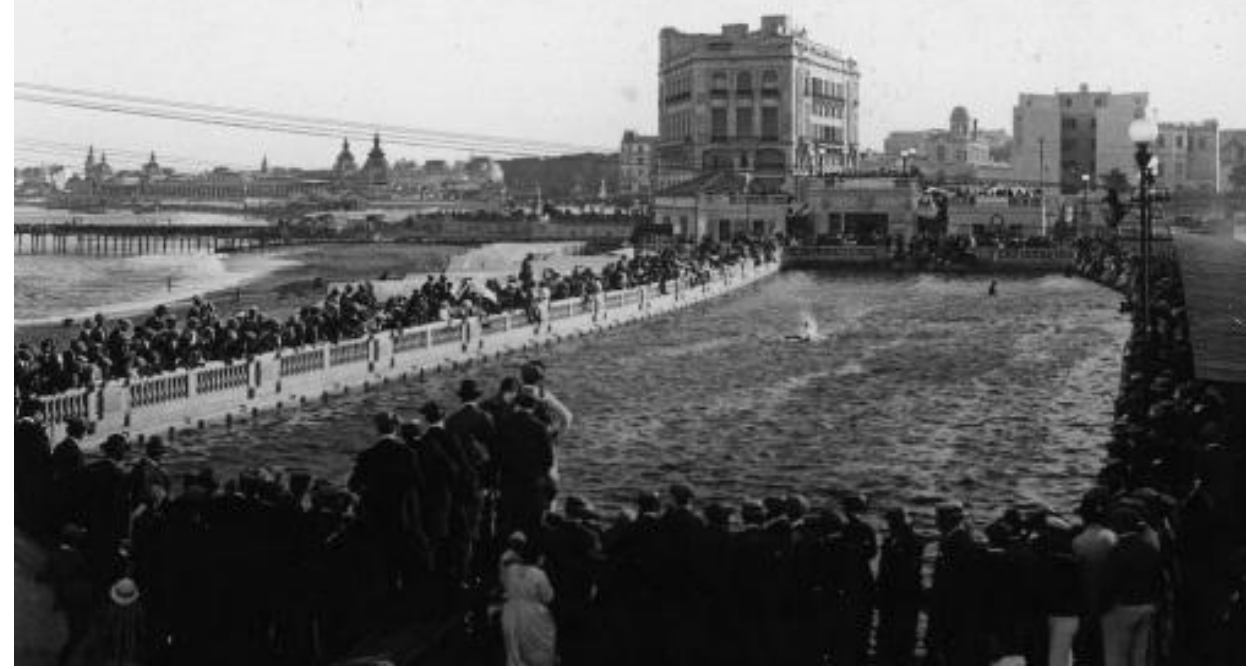

Figura 11: Pileta Lavorante circa 1920. Archivo Fotos de Familia. Diario La Capital. Mar del Plata.

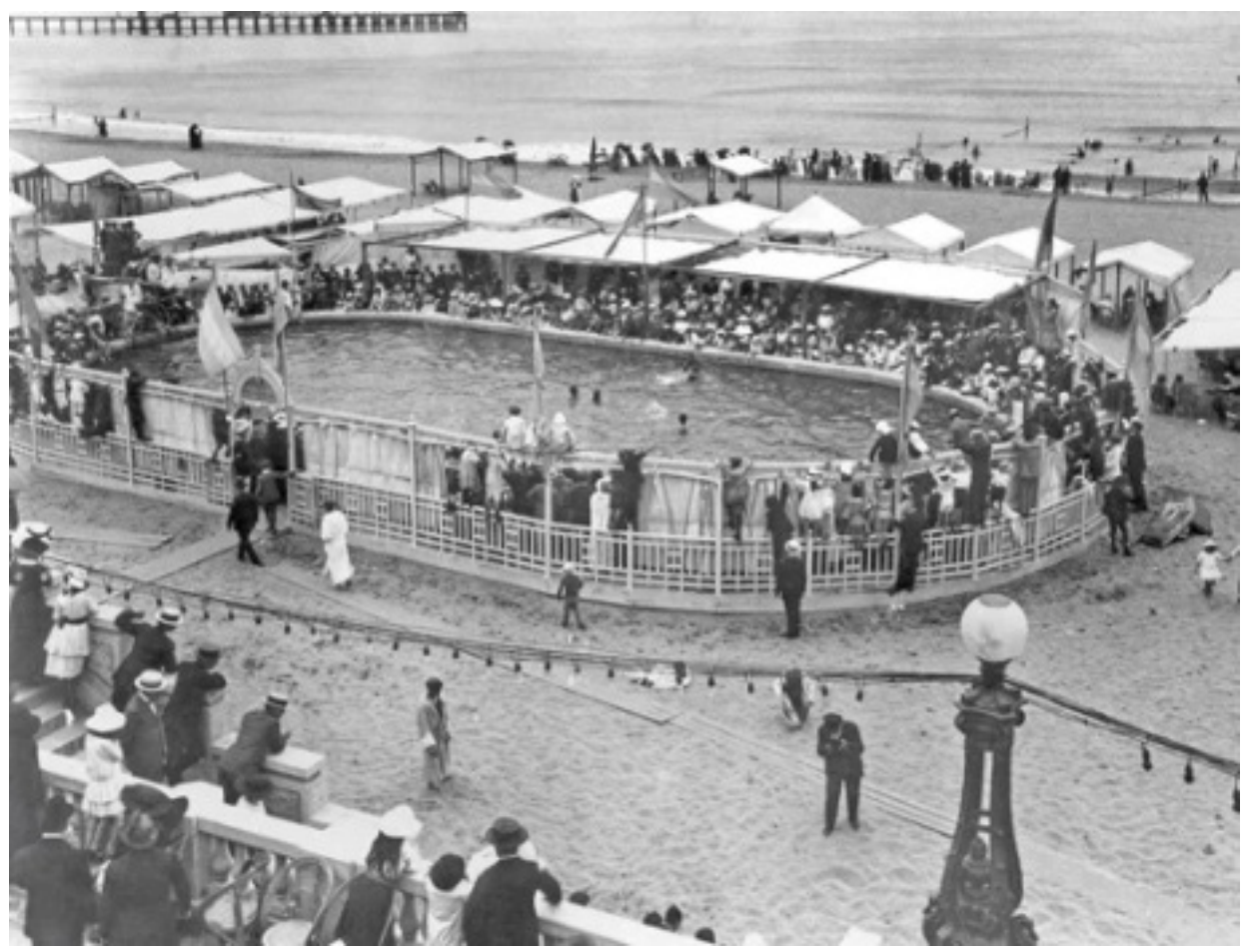

Figura 12: Pileta Giaccaglia Playa Bristol, 1915. Archivo Fotos de Familia. Diario La Capital. Mar del Plata. 


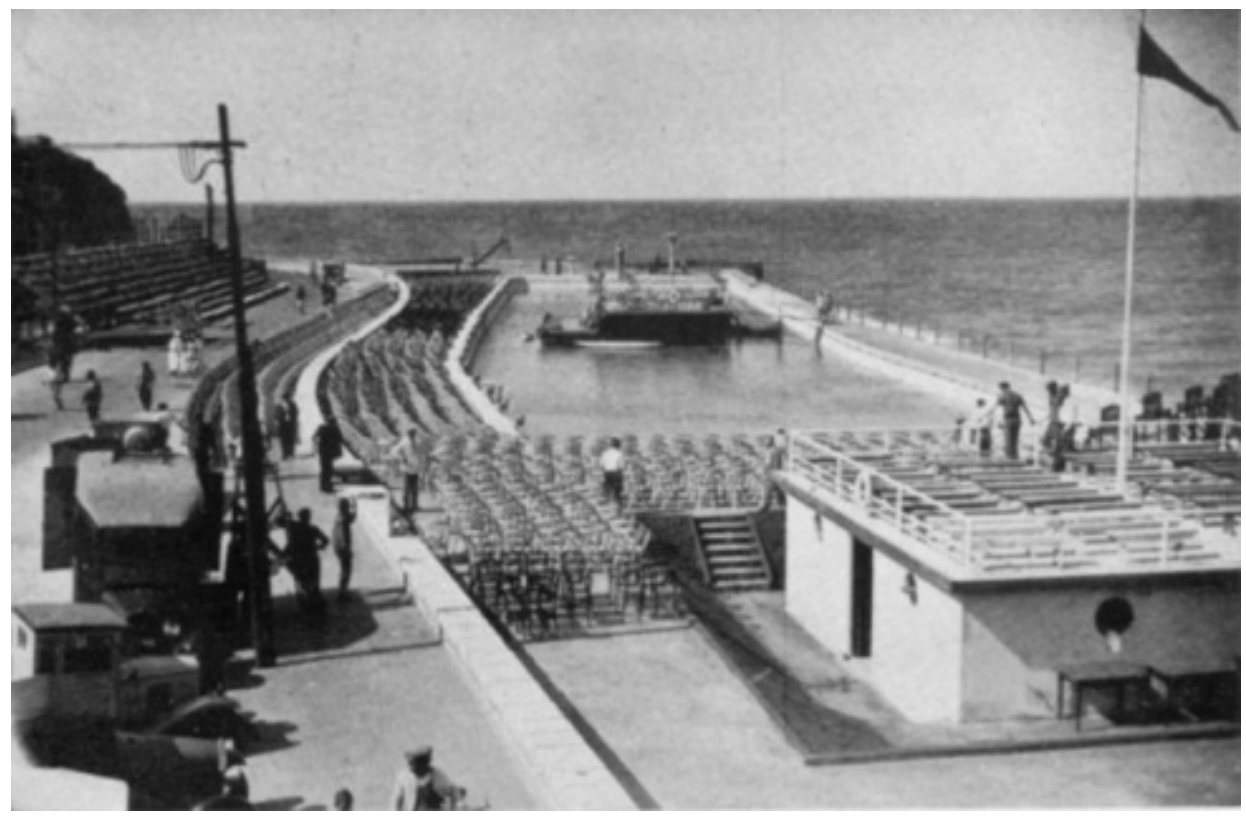

Figura 13: Pileta Municipal como escenario Opera Marina del maestro Arrieta, 1935. Boletín Municipal, Archivo Fotos de Familia, Diario La Capital

Al ligar el interés de los que juegan y compiten con los que miran y disfrutan del espectáculo, el espacio deportivo traduce necesariamente unas exigencias que no son intrínsecamente las del deporte sino las de la sociedad entera (Chartier, Vigarello, 1982: 292). También esto es una conquista del individuo moderno, la capacidad de observación de prácticas deportivas en el marco del ocio como ritos que deleitan, activan la adrenalina y conmocionan.

\section{Marcas de género}

Las relaciones de las mujeres con el deporte siempre han sido motivo de discusión. ${ }^{9}$ Algunas voces defendían la afición señalando que nunca había estado tan de moda el gusto por los deportes para adquirir la gracia y el garbo en las actitudes y en la manera de andar. Justamente, la cultura física, en su generalidad, era un medio para cultivarlas. Era especialmente útil para obtener la línea, ligereza y flexibilidad y contribuía a paliar las imperfecciones que le venían por defecto, tanto por el sedentarismo como por las secuelas físicas que dejaban las marcas de la maternidad, entre otras representaciones inherentes a su género.

Se alentaba a comprender que el estímulo no era competir por la conquista del primer lugar y su gloria sino, cumplir con cierta sistematización para producir belleza y salud.

Los deportes fueron el factor principal de su conquista. La mujer comenzó por asistir a los torneos como una simple espectadora. Poco a poco, en nombre de la higiene, dedicó los domingos a practicar, tímidamente, los juegos más sencillos, sin darle carácter de espectáculo público.

9 Algunas de estas cuestiones más recientes pueden verse en Scharagrodsky Pablo (Coord.) (2007). Mujeres en movimiento. Deporte, cultura física y feminidades. Buenos Aires: Prometeo. 
"Por qué permite usted - le decían a un padre - que su hija juegue lo mismo que los hombres? - Se lo permito en nombre de la salud, pues desde que practica los deportes, luce mejor color; está más fuerte; come con mayor apetito; nunca precisa médico" (Caras y Caretas, 1931, $\left.n^{\circ} 1729\right)$.

A pesar de esto, tenía fuertes críticas desde diferentes sectores. El temor residía en virilizar al sexo débil, contrariar las formas honradas de la apariencia, perturbar los comportamientos. Resonaba la inquietud por desestabilizar un sistema afirmado en las asimetrías sociales, por alterar las sensibilidades que durante largo tiempo identificaron las incumbencias de los géneros. Otros detractores sostenían que la actividad física femenina debía comprender el cuerpo entero y no sólo grupos musculares o unas regiones en detrimento de otras, de allí que no fueran las formas de un deportista ni mucho menos las de un atleta las adecuadas para alimentar delicadeza, feminidad y lozanía.

Es así que se prefirieran algunos deportes sobre otros, aunque, en realidad, los fundamentos fuesen más del orden de las supersticiones que dé la razón. La natación parecía estar entre los deportes aceptados “...las damas del presente se entregan con entusiasmo a la natación, la que impone el mínimum de topas y la mayor libertad de movimientos" (Caras y Caretas, 1933, n¹838) parecía tener el privilegio de mantener la armonía y belleza de líneas de la mujer que la practicaba.

La prensa gráfica no desdice la propuesta. Entre las primeras notas que alientan la práctica se prescribe que por higiene y por estética toda joven que se mete en el mar debe sentir estímulos y deseos de aprender a sostenerse en las olas. Sin despegarse de las marcas culturales del género se anuncia que "una mujer nadando no es ciertamente un ser vulgar nunca, y en la natación caben tantas coqueterías y tantos refinamientos como en el andar a pie en tierra firme" (Caras y Caretas, 1905, n³77).

Hacia 1920 se asegura que adquieren cada día más interés e importancia las pruebas de natación en las que compiten sólo las mujeres por el crecido número de aficionadas que en ellas toman parte, despojándose de vanos prejuicios para entregarse al disfrute del deporte. ${ }^{10}$ Las fotografías parecen publicarse como pruebas de lo que exponen los textos, de cuán grande es el entusiasmo de la mujer por aprender a nadar, sobre la concurrencia numerosa a las piletas y los baños de mar, sobre la exaltación del cuerpo en traje de baño.

Se reivindica la capacidad física, la destreza, el desempeño comparable al sexo opuesto. Sin embargo, la práctica femenina nunca deja de generar controversias y ser tema de comentario, aún en los círculos más distinguidos.

El hecho de que mujeres de la sociedad expongan sus cuerpos esculturales y las habilidades de la natación en las crónicas sociales revisteriles, ya sea en los escenarios más públicos como los balnearios o en la intimidad de las piletas privadas de las viviendas, ponía en tensión la rigurosa moral.

Una de las grandes controversias era, sin dudas y como se anticipó, el traje de baño. Mientras unos aprobaban las innovaciones, fundados en que el traje ligero y práctico prestaba libertad a los movimientos, permitiendo a las bañistas nadar y gozar

10 La natación como deporte profesional, inicialmente para varones, se concretó a finales del siglo XIX. Habría que esperar hasta el año 1909 para que una mujer, Annet Kellerman lograra consolidar el espacio de desempeño femenino, siendo la pionera en nado sincronizado a nivel profesional. Es posible que esto haya sido un estímulo para quienes se animaran a la práctica de forma amateur. Las competiciones femeninas de natación se incluyeron por primera vez en los Juegos Olímpicos de 1912. 
plenamente de sus miembros al aire libre, en beneficio indudable de la salud física, otros deploraban tales cosas, tratándolas de inmorales, perniciosas, viendo en ellas el signo evidente de la decadencia de la época (Caras y Caretas, 1915, n888).

Una buena nadadora debía buscar, "antes que nada todo el confort posible para sus movimientos y sacrificará hasta la elegancia por su comodidad, que le permita dedicarse a las expansiones náuticas" (Caras y Caretas, 1915, $n^{\circ}$ 851). Ciertamente, el tono imperativo del texto no aseguraba la conformidad por parte de todas las bañistas. Según se anuncia en la prensa, el diseño y la composición textil de los trajes de baño conciliaban las exigencias de la natación y los deseos de la coquetería.

Hacia 1930 se describe un corte "inteligente" de malla sintética y corta que emplea los recursos de la corsetería para adaptarse al cuerpo como si fuera una piel y facilitara la libertad de movimientos, soportar ventajosamente la acción del agua y los baños de sol de acuerdo con las recomendaciones de los higienistas (Caras y Caretas, 1933, $n^{\circ} 1838$ ). La nota añade otro modelo, que es el que está reservado a las personas que tienen la fortuna de poder bañarse en playas privadas o salir en embarcaciones a cierta distancia de la costa. Este es otro caso en el cual queda clara la referencia al ocio en el marco del deporte, como delimitador de estilos de vida y diferenciaciones sociales.

A partir de un registro elaborado sobre avisos de este tipo, la iconografía expresa que se van desplazado los estereotipos decimonónicos porque el lenguaje corporal se presenta menos escoltado por el pudor y la distancia entre sexos. Puede verse cómo una apariencia rediseñada venía junto a directrices comportamentales que demandaban desvergüenza y libertad, ligada a la transformación en el uso del espacio costero (Kaczan, 2012).

Cada vez más, la imaginería de la cultura visual asociada con el turismo, con el deporte y con los productos de belleza orientados al cuerpo en el exterior, apostó por escenas de mujeres vinculadas con la natación y los deportes acuáticos (Figura 14, Figura 15, Figura 16).

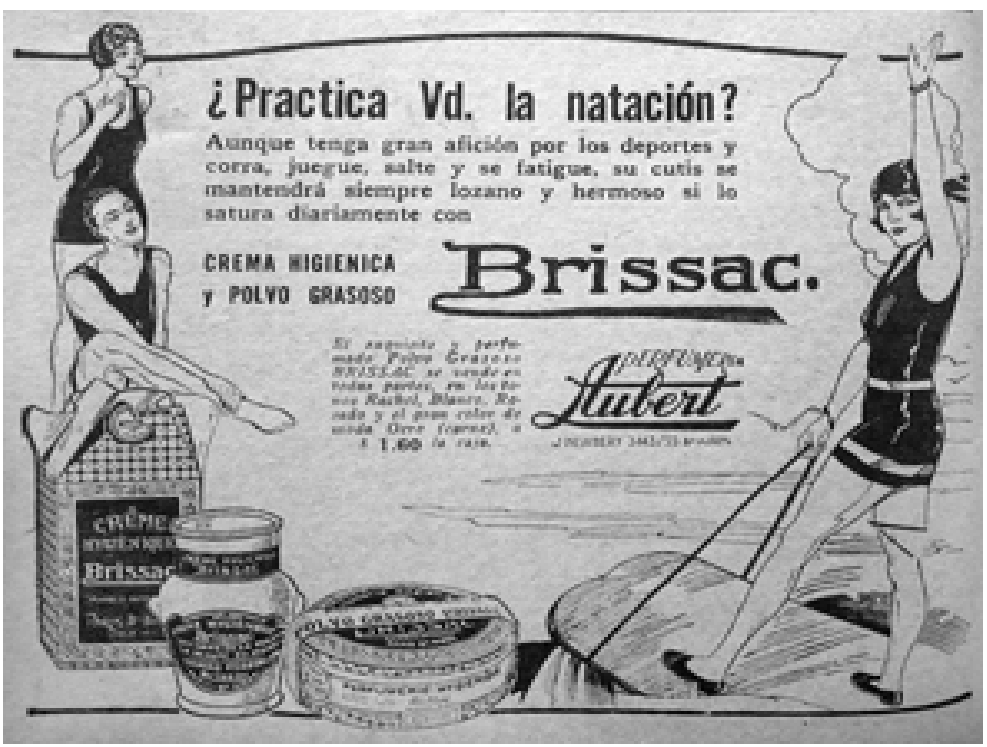

Figura 14: Aviso de Brissac, Caras y Caretas (1926). Buenos Aires, año XXIX, nº 1429. 


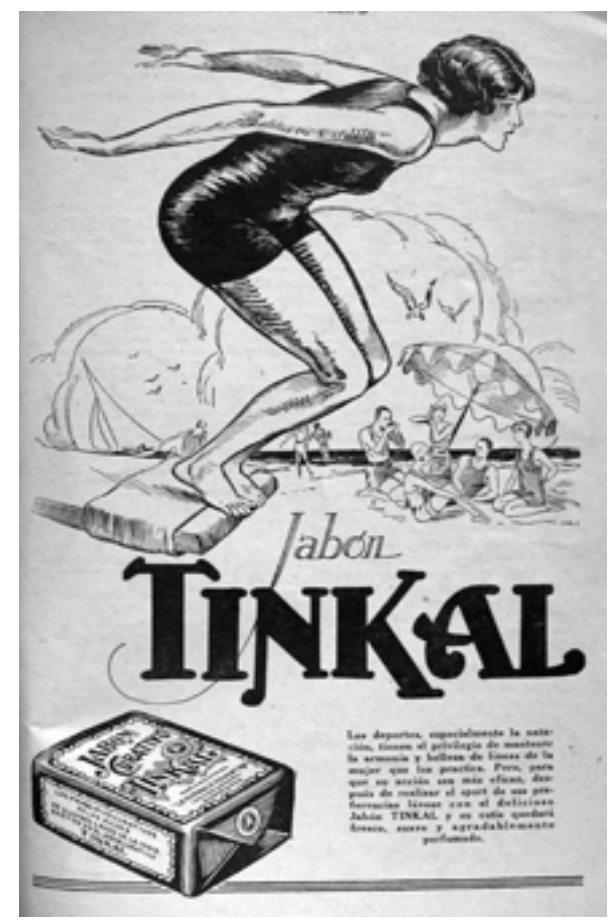

Figura 15:Aviso Tinkal, Caras y Caretas (1929). Buenos Aires, año XXXII, $\mathrm{n}^{\circ} 1562$.

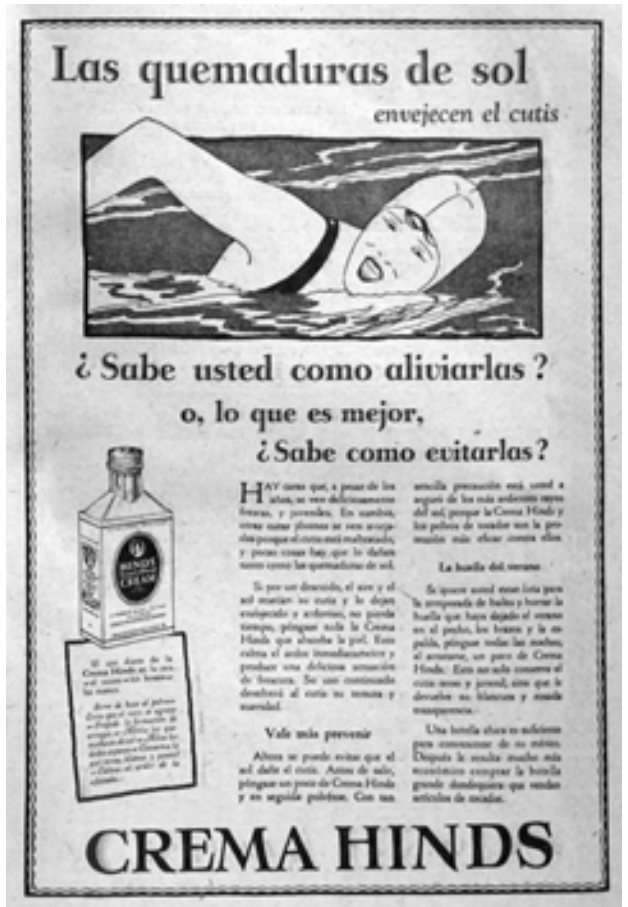

Figura 16: Aviso Hinds, en Caras y Caretas (1929). Buenos Aires, año XXXII, n¹629. 
El lenguaje del cuerpo pretende responder a las nuevas libertades que surgen de la cultura física, da la sensación que se está frente a mujeres más independientes. Es sugestivo el uso reiterado de figuras en situación de expansión corporal, desarrollando destrezas o en escenas de sociabilidad inter-intragenéricas. Y se explota al límite la sensación de instantaneidad, son captadas en la plenitud de su movimiento, en la plasticidad de su cuerpo, en actitud de disfrute y de lucimiento personal. El balneario es un espacio donde ensayar, poner en práctica y predecir comportamientos que terminan forjando imágenes, imágenes que mujeres y varones captan y transfieren.

Quizás algunas de estas sean imágenes que anticipen realidades, justamente en este proceso reside lo significativo. Lo alentador es que las aficiones que acercan el cuerpo femenino a la naturaleza y al disfrute del desempeño físico se imponen como parte fundamental de los cuerpos modernos en su integridad.

\section{Conclusiones}

Los análisis efectuados han permitido verificar las interconexiones entre el cuerpo, la cultura, el deporte y el agua, poniendo especial atención en la práctica de la natación recreativa como deporte que, desde el marco de la historia cultural, constituye un campo original donde se especifican gestos, espacios, tiempos, marcas políticas y de género, entre otras tantas.

En el inicio se comprendió como las aguas de mar y océano revierten su significado de acuerdo con los saberes que proponen que sus aguas reestablecen la armonía corporal, calman las ansiedades, alivian numerosas dolencias y males psicofísicos y afecciones emocionales. En consecuencia, nuevos hábitos saludables se retroalimentaron en la permanencia al exterior y se tejieron experiencias culturales asociadas con los beneficios del aire libre.

Esto vino de la mano del desarrollo de formas arquitectónicas originales y de la emergencia de una dimensión corporal específica, de una relación particular con el cuerpo en movimiento.Grandes obras de infraestructura, como las piletas en los complejos balnearios, diseñaron sitios de encuentro y una serie de actividades culturales que favorecieron la conexión de las sociabilidades con las prácticas del deporte como entretenimiento. Se aunó la convivencia de diferentes figuras y diferentes aspiraciones, se trató de satisfacer los gustos de los amantes de los deportes de agua para quienes se entrenaban y participaban de las competencias o demostraciones, para los aprendices y los amateurs. Y, también, de un gran número de espectadores que apreciaba el desarrollo de esas destrezas con la posibilidad de disfrutar de las visuales hacia el mar en las proximidades del entorno.

Las prestaciones de los balnearios se fueron complejizando, tanto por las coyunturas políticas como por las experiencias culturales que acortaban las distancias con la naturaleza, implicando cambios en los estilos de vida. Se erigieron obras arquitectónicas en las cuales se dio el doble proceso social de diferenciarse y emular: los balnearios más populares, hacia la zona centro del borde costero, y los balnearios más distinguidos hacia la zona sur. Asimismo, se dio cada vez más lugar a lo sensorial y al placer sobre lo controlado e higiénico, sumando provechos.

La posibilidad implícita de los baños que llegan para instalarse en el imaginario como un complemento para lograr salud y otorgar diversión, dieron lugar, también, al desnudamiento progresivo del cuerpo. Y, en este pasaje, las mujeres encontraron una vía para conquistar espacios negados y controversiales. 
Resulta estimulante y sugestiva, para sintetizar icónicamente algunos de los procesos estudiados, la interpretación del diseño de portada de dos de los manuales consultados (Figura 17).

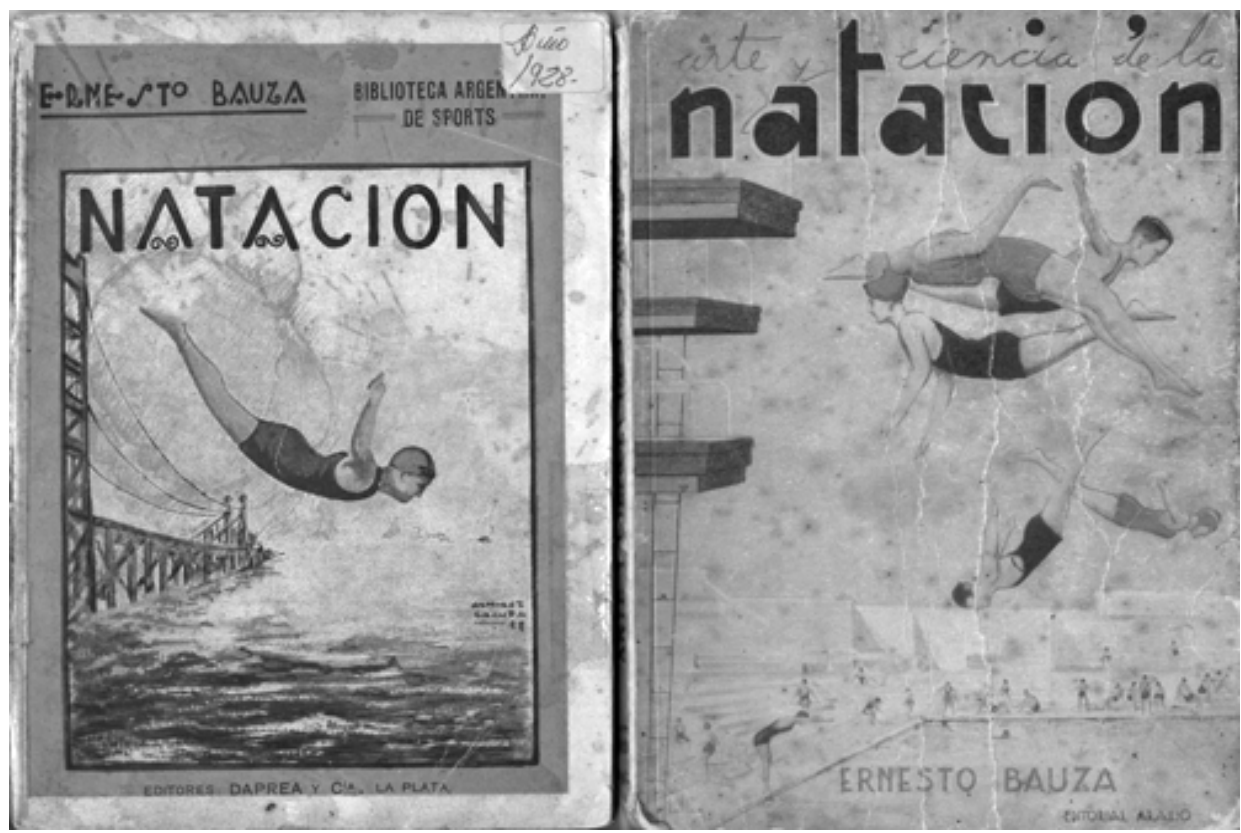

Figura 17: Bauza, E. (1928). Natación. Buenos Aires: Araujo./ Bauza, E. (1935).

Arte y ciencia de la natación. Buenos Aires: Araujo.

En la imagen que data de la década de 1920, un cuerpo masculino es captado en el aire en un salto adelante, instantes previos a zambullirse, sin saber de qué lugar ha partido. Se da idea de aguas abiertas, de mar u océano, interceptadas por un gran puente, producto de la ciudad modernizada y por un velero que apenas se vislumbra en el fondo, como indicativo de alguna práctica de descanso de grupos más privilegiados, los primeros veraneantes.

En la otra tapa de la década de 1930 los personajes se han multiplicado y el escenario es otro. Dos mujeres y tres varones, en diferentes tipos de saltos ornamentales y en diferentes tiempos, son retratados en el primer plano de lectura, contiguos a trampolines y una escalera que los une. Por debajo y en un segundo plano, grupos mixtos se dibujan en tamaño reducido practicando destrezas alrededor de una pileta de natación, donde caerán los protagonistas principales. Sin detener la atención en la técnica de cada ilustración, que también se ha modificado de acuerdo con la tendencia artística contemporánea, las escenas en el nivel de la presentación, estarían poniendo en evidencia la creciente aceptación de la práctica del nado por parte de grupos más numerosos y plurales. Las mujeres se mantienen a la par de los varones y se distingue la afluencia de las piletas como espacios de complejas estructuras que albergan, no sólo competencias, adiestramientos o juegos sino, también, la posibilidad de disfrutar en compañía de los otros, la expectación de los curiosos, la oportunidad de involucrarse en hábitos corporales que provocan bienestar. 
Esto conlleva a pensar que los cuerpos estuvieron cada vez más ligados al tiempo de descanso, a practicar un deporte y a la relación con la naturaleza y las emociones. Estas son algunas de las características que refieren a los cuerpos como modernos, que reflejan los cambios culturales que se van encausando hacia la segunda y tercera década del siglo XX y que adoptan nuevas imágenes en la apariencia. Criterios que se afianzan por un largo período en la historia. 


\section{Bibliografía}

Aresti, N. (2001). Médicos, donjuanes y mujeres modernas. Bilbao: Servicio Editorial Universidad del País Vasco.

Anesti, J. (1927). Guía Turística del Sud. Buenos Aires: Asociación de Propaganda y Fomento de Mar del Plata.

Arias Trujillo, R., Pujadas i Marti, X. (2016). Presentación del dossier Deporte y sociedad. Historia Crítica. Bogotá: Universidad de los Andes, n 61, pp.13-21.

Armus, D. (2007). La ciudad impura. Salud, tuberculosis y cultura en Buenos Aires. 18701950. Buenos Aires: EDHASA.

Atlántida (1940). Buenos Aires, $s / n^{\circ}$

Bauza, E. (1935). Arte y ciencia de la natación. Buenos Aires: Araujo.

Bauza, E. (1928). Natación. Buenos Aires: Araujo.

Bohem, G. (1994). Was istein Bild? Munich: Fink, pp 11-38.

Bourdieu, P. (1991). La distinción. Criterio y bases sociales del gusto. Madrid: Taurus.

Bourdieu, P. (1992). How can one be a sports fan? En E. During (Ed.).The cultural studies reader, pp.339-356. Londres: Routledge.

Bouza, J. (2000). La difusión de la innovación científica y el desarrollo de la balneoterapia: la incorporación de los procesos de la química. Scripta Nova. Revista Electrónica de Geografía y Ciencias Sociales, $n^{\circ} 69$ (39), pp.1-8.

Brea, J.L. (ed.) (2005). Estudios Visuales. La epistemología de la visualidad en la era de la globalización. Madrid: AKAL.

Burke, P. (2000). Formas de Historia Cultural. Madrid: Alianza Editorial.

Cabrera M. Guarín, O. (2012). Presentación. Imagen y ciencias sociales: trayectorias de una relación. Memoria y Sociedad. Bogotá-Colombia, vol. 33, pp. 7-22.

Caras y Caretas (1902). Buenos Aires, año V, nº 175.

Caras y Caretas (1905). Buenos Aires, año VII, $n^{\circ} 377$.

Caras y Caretas (1909). Buenos Aires, año XII, n 537.

Caras y Caretas (1909). Buenos Aires, año XII, $n^{\circ} 538$.

Caras y Caretas (1914). Buenos Aires, año XVII, nº 803.

Caras y Caretas (1915). Buenos Aires, año XVIII, n 851.

Caras y Caretas (1915). Buenos Aires, año XVIII, n 888.

Caras y Caretas (1926). Buenos Aires, año XXIX, n 1429.

Caras y Caretas (1927). Buenos Aires, año XXX, n 1479.

Caras y Caretas (1929). Buenos Aires, año XXXII, $n^{\circ} 1562$.

Caras y Caretas (1929).. Buenos Aires, año XXXII, n 1629.

Caras y Caretas (1931). Buenos Aires, año XXXIV, n 1729.

Caras y Caretas (1933). Buenos Aires, año XXXVI, n 1838. 
Corbin, A. (1993). El territorio del vacío. Occidente y la invención de la playa (1750-1840). París: Biblioteca Mondadori.

Comisión Pro Mar del Plata (1928). Mar del Plata. Primer Balneario de Sud América.

Corbin, A., Courtine, J.-J., Vigarello G.(2006). Historia del cuerpo. Barcelona: Taurus.

Cuenca Cabeza, M., Goytía Prat, A. (2012). Ocio experiencial: antecedentes y características. Arbor. Ciencia, Pensamiento y Cultura. Madrid, vol. 188, pp.265-281.

Chartier, R. y Vigarello, G. (1982). Las trayectorias del deporte. Prácticas y espectáculo, Apunts, vol. XIX, 289-305.

Didi-Huberman, G. (2008). Cuando las imágenes toman posición. Madrid: A. Machado Libros.

Dumazedier, J. (1964). Hacia una civilización del ocio. Barcelona: Editorial Estela.

Elías N. y Dunning E. (1992). Deporte y ocio en el proceso de la civilización. Madrid: Fondo de Cultura Económica.

Fray Mocho (1914). Buenos Aires, año III, nº 135.

Geertz, C. (1992). La interpretación de las culturas. Barcelona: Gedisa.

Goffman, E. (1988). Los momentos y sus hombres. Barcelona: Paidós.

Guttmann, A. (1978). From Ritual to Record: The Nature of Modern Sport. Nueva York: Columbia University Press.

Hau M. (2003). The Cult of Health and Beauty in Germany: A Social History 1890- 1930. Chicago and London: The University of Chicago Press.

Jodelet, D. (2007). Imaginaires érotiques de l'hygiène féminine intime. Connexions, $\mathrm{n}^{\circ} 87$, pp.105-127.105-127.

Kaczan, G. (2012).Figuras femeninas en la mira. Cuerpos, vestidos, imágenes en las dos primeras décadas del siglo XX. Mora. Buenos Aires: Facultad de Filosofía y Letras, Universidad Nacional de Buenos Aires vol. 18, $\mathrm{n}^{\circ} 1$.

Kaczan, G. (2016). La práctica gimnástica y el deporte, la cultura física y el cuerpo bello en la historia de las mujeres. Argentina 1900-1930. Historia Crítica. Bogotá: Universidad de los Andes, Colombia. $n^{\circ} 61$, pp. 23-43.

Lamas, M. (2002). Cuerpo: Diferencia sexual y género. México: Taurus.

Le Goff, J.; Roger C., Jacques R. (1988). La nueva historia. Bilbao: Mensajero.

Lencek L. y Bosker G. (1998). La playa: La historia del paraíso sobre la Tierra.Londres: Viking.

Levi, G. (1993). Sobre microhistoria. Buenos Aires: Biblos.

Love, C. (2008). A social History of Swimming in England, 1800-1918. New York, USA.

Massey D. (2004). "Lugar, identidad y geografías de la responsabilidad enun mundo en proceso de globalización”. Treballs de la Societat Catalana de Geografia, n 57,pp. 77-84.

Mitchell, W.J.T. (2005). What Do Pictures Want? The Lives and Loves of Images. Chicago: Chicago Press. 
Moxey, K. (2009). "Los estudios visuales y el giro icónico". Revista Estudios Visuales. España $n^{\circ} 6$, pp. 8-27.

Pastoriza, E. (2002). Las puertas al mar. Consumo, ocio y política en Mar del Plata, Montevideo y Viña del Mar. Buenos Aires: Biblos.

Pecout, C. y Birot L. (2008). La culture sportive mondaine à la Belle Époque: facteur du développement des stations balnéaires du Calvados. Annales de Normandie, vol. 58, $\mathrm{n}^{\circ} 1-2, \mathrm{pp} .135-146$.

Piglia M. (2014). Autos, rutas y turismo. El Automóvil Club Argentino y el Estado.Buenos Aires: Siglo XXI.

Plus Ultra (1922). Buenos Aires, año VII, nº 70.

Reggiani, A. (2015). Eugenesia y cultura física. Tres trayectorias históricas: Francia, Gran Bretaña y Argentina. En Scharagrodsky P. (comp.) Miradas médicas sobre la cultura física en Argentina 1880-1970. Buenos Aires: Prometeo, pp. 17-58.

Rodríguez-Suárez, J. y Argulló E. (2002). Psicología social y ocio: una articulación necesaria. Psicothema, vol. 14, $\mathrm{n}^{\circ} 1$, pp. 124-133.

Staffe, B. (1899). Le Cabinet de Toilette. París: Ernest Flammarion Editeur.

Tossounian, C. (2010). The Body Beautiful and the Beauty of Nation: Representing Gender and Modernity (Buenos Aires 1918-1939). Tesis Doctoral. Florence: European University Institute.

Van Leeuwen, T. (2000). The Springboard in the Pond: An Intimate History of the Swimming Pool. Graham Foundation / MIT Press Series in Contemporary Architectural Discourse.

Villar Molina, J. J. (2004). Termalismo y turismo en Catalunya. Un estudio neohistórico contemporáneo. Tesis Doctoral, Departamento de Geografía Física y Análisis Geográfico Regional. Facultad de Geografía e Historia, Universidad de Barcelona.

Vigarello, G. (2005). Corregir el cuerpo. Buenos Aires: Nueva Visión.

Vigarello, G. (2007). Historia de la belleza. Buenos Aires: Nueva Visión.

Viva Cien Años (1940). Buenos Aires, vol. X, n6.

Viva Cien Años (1940). Buenos Aires, vol. VIII, $n^{\circ} 7$.

Viva Cien Años (1942). Buenos Aires, vol. XII, n8.

Walton, J. (2008). Beaches, Bathing and Beauty: Health and Bodily Exposure at the British Seaside from the Eighteenth Century to the Twentieth. Revue Francaise de Civilization Britannique, $\mathrm{n}^{\circ} 14$, pp. 36-119.

Wiltse, J. (2007). Contested Waters. A social history of swimming pools in America. USA: University of North Carolina Press.

Zuppa, G. (2012). Bajo otros soles. Miradas a través de folletos, postales, avisos publicitarios y fotografías. Mar del Plata 1900-1970. Mar del Plata: Eudem.

Zuppa, G. (2014). La construcción de la imagen de Mar del Plata (1874-1945). Estudios Visuales de la ciudad como aportes para el campo de análisis social. Mar del Plata: Tesis de Maestría, Facultad de Humanidades. Universidad Nacional de Mar del Plata. 